Review

\title{
The impact of chromatin regulation on the floral transition
}

\author{
Sara Farrona, George Coupland, Franziska Turck* \\ Max Planck Institute for Plant Breeding Research, Department Plant Developmental Biology, Carl von Linné Weg 10, 50829 Köln, Germany
}

\section{A R T I C L E I N F O}

\section{Article history:}

Available online 30 July 2008

\section{Keywords:}

Chromatin

Transcription regulation

Floral transition

Histone modification

\begin{abstract}
A B S T R A C T
Transcription in eukaryotes is regulated by many enzymes that influence the nuclear organization of DNA in chromatin. Several of these enzymes regulate histone modifications. These modifications function as a platform for assembly of protein complexes that influence chromatin structure. Dynamic changes between chromatin states that facilitate or inhibit transcription are important in the transcriptional regulation of pathways controlling floral induction in response to environmental and developmental signals. This review focuses on the mechanistic aspects of histone modifications and chromatin changes at floweringtime genes and how these relate to the initiation of flowering.
\end{abstract}

(c) 2008 Elsevier Ltd. All rights reserved.

\section{Contents}

1. Introduction.....

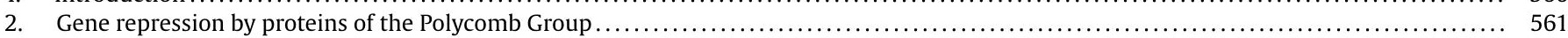

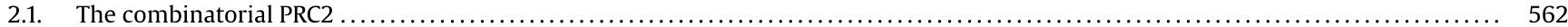

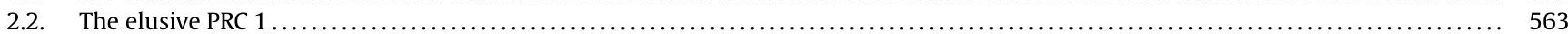

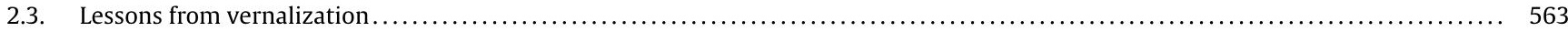

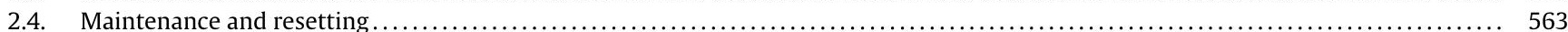

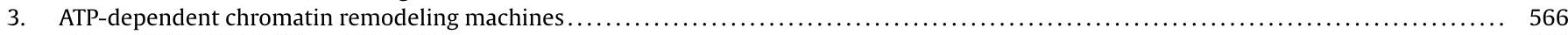

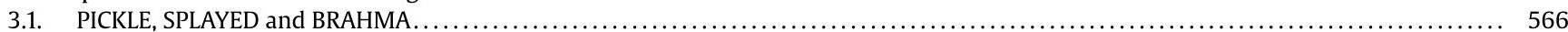

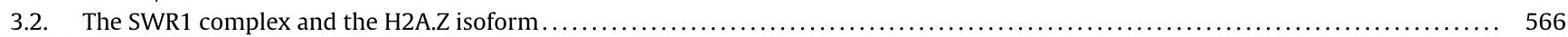

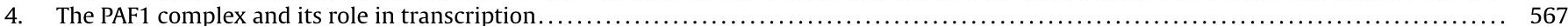

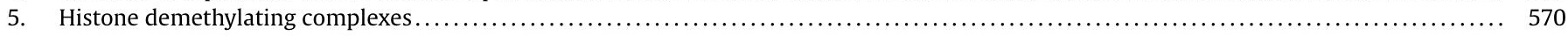

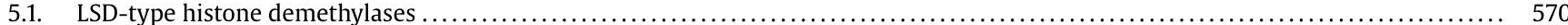

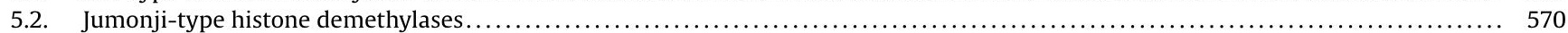

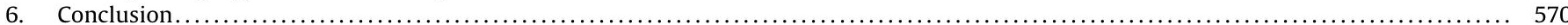

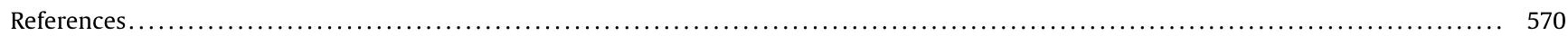

\section{Introduction}

Reproductive success of a plant depends on flowering at the right time, a decision that not only involves the perception of external cues but is also dependent on internal developmental parameters. In the model plant Arabidopsis thaliana, the photoperiod and vernalization pathways promote flowering through the perception of long days (LD) and prolonged cold exposure, whereas the Gibberellic acid (GA)-dependent and autonomous pathways are controlled by internal cues. Importantly, the pathways converge at the level of transcription of several genes, sometimes designated as

\footnotetext{
* Corresponding author. Tel.: +49 221 5062246; fax: +49 2215062207

E-mail address: turck@mpiz-koeln.mpg.de (F. Turck).
}

pathway integrators, which are representatives of highly regulated and complex expression modules. The regulation of floral pathway integrators has been correlated with many chromatin-associated phenomena. Our review will focus on the mechanistic aspects of chromatin changes that are observed at flowering pathway integrator genes.

Several recent reviews have presented details on the temporal and spatial regulation of the genetic network that underlies the transition to flowering [1,2]. Here, we will briefly introduce the most important convergence points within the flowering network that will be mentioned in the context of chromatin regulation later in the text (Fig. 1). Early flowering under long summer days involves activation of transcription of FLOWERING LOCUS T (FT) toward the end of the day because the protein product of its upstream activator CONSTANS (CO) is stabilized by light at this time. FT protein 


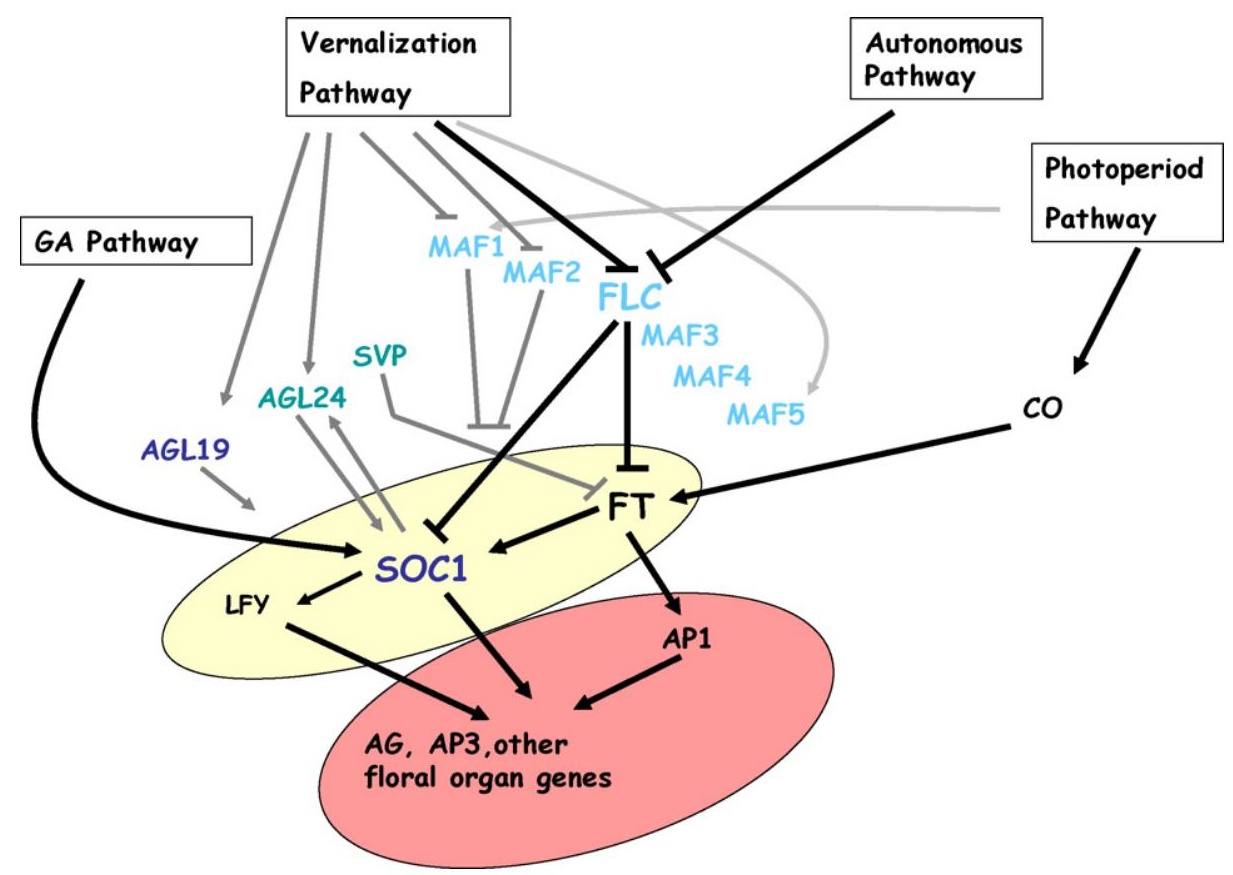

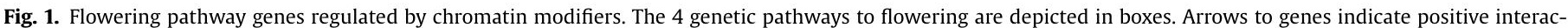

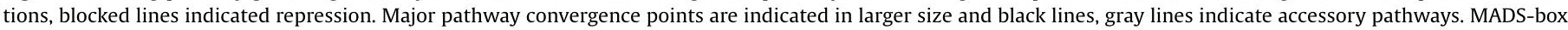

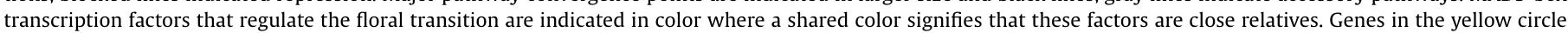
predominantly define inflorescence identity; genes in the red circle define floral identity.

moves from the site of production in the phloem companion cells of leaves to the apex where it rapidly causes the upregulation of SUPPRESSOR OF OVEREXPRESSION OF CONSTANS 1 (SOC1), which encodes a MADS box transcription factor, and less directly of $L E A F Y$ $(L F Y)$, which encodes a plant-specific transcription factor. These factors are involved in reprogramming the shoot apex from a vegetative to an inflorescence meristem. Subsequently, genes expressed specifically in the floral primordium such as APETALA 1 (AP1) and floral organ identity genes such as AGAMOUS $(A G)$ and $A P 3$ are expressed.

Arabidopsis accessions that require vernalization, extended exposure to low temperatures, to induce early flowering, express high levels of the MADS-box factor FLC due to an active allele of FRIGIDA (FRI). In these plants flowering is suppressed by direct repression of FT and SOC1 by FLC [3,4]. There are five FLC-related loci in Arabidopsis, the MADS AFFECTING FLOWERING genes (MAF 1-5) that are co-regulated in some but not all physiological and genetic conditions. The MAFs likely also act as flowering repressors and this has been confirmed for MAF1 (also named FLM and AGL27) and MAF2 (also named AGL31) [5-8]. FLC expression by vernalization is stable even after a return to warmer temperatures [9-11]. Expression of $F L C$ is also regulated by the autonomous pathway that represses FLC independently of vernalization late in development.

The GA-dependent pathway bypasses the requirement for FT induction and repression by FLC and promotes the expression of SOC1 and other genes by unknown mechanisms. Several additional MADS-box factors have an impact on flowering; AGL24 and AGL19, the closest relative of SOC1, promote flowering. AGL19 is part of an FLC-independent vernalization-responsive pathway [8] and AGL24 expression is stimulated by vernalization independent of FLC [12]. AGL24 and SOC1 mutually stimulate each other's expression and interact to activate the expression of $L F Y[13,14]$. Such interactions likely contribute to the integration of different flower promoting signals such as GA and vernalization perception. Interestingly, SHORT VEGETATIVE PHASE (SVP), the Arabidopsis protein most related to AGL24, acts as a repressor of flowering by direct repression of FT [15].

Transcription of floral integrator genes, like all other eukaryotic genes, requires an open chromatin structure where nucleosomes are arrayed like beads on a string. Usually, chromatin is further compacted by intranucleosomal interactions which also depend on the linker Histone 1 (H1). Several chromatin factors implicated in the regulation of floral pathway integrators act at the level of chromatin compaction.

Nucleosomes are composed of 147 base pairs of DNA wrapped around histone octamers in 1.65 superhelical turns: two $\mathrm{H} 3-\mathrm{H} 4$ dimers at the core flanked by two H2A-H2B dimers [16]. Even in an open chromatin conformation, nucleosomes form a strong barrier to transcription. The assembly of the large multi-protein Pre-initiation Complex (PIC) at the transcriptional start site requires a nucleosome-free region. In addition, RNA Polymerase II (RNPII) transcription through nucleosomal templates requires the removal of at least one $\mathrm{H} 2 \mathrm{~A} / \mathrm{H} 2 \mathrm{~B}$ dimer from nucleosomes and the regulated repositioning of nucleosomes situated ahead of elongating RNPII to a position behind it $[17,18]$. Chromatin factors that participate in the transcriptional process per se are also crucial for the expression of floral pathway integrators.

\section{Gene repression by proteins of the Polycomb Group}

Methylated lysine residues of the amino-termini tail of $\mathrm{H} 3$, in particular at position 9 and 27, provide chromatin marks that are thought to act as an assembly platform for repressive complexes. Recent genomic studies in Arabidopsis have identified a surprisingly large number of genes (ca. 15\% of all genes) that are marked by H3K27me3 $[19,20]$. Most H3K27me3 marked genes are lowly expressed throughout development or are expressed in a strikingly tissue-specific pattern. Many H3K27me3 targets play a confirmed role in flowering-time regulation and other developmental processes. All flowering pathway genes introduced earlier, with the notable exception of $\mathrm{CO}$, are $\mathrm{H} 3 \mathrm{~K} 27 \mathrm{me} 3$ targets. 

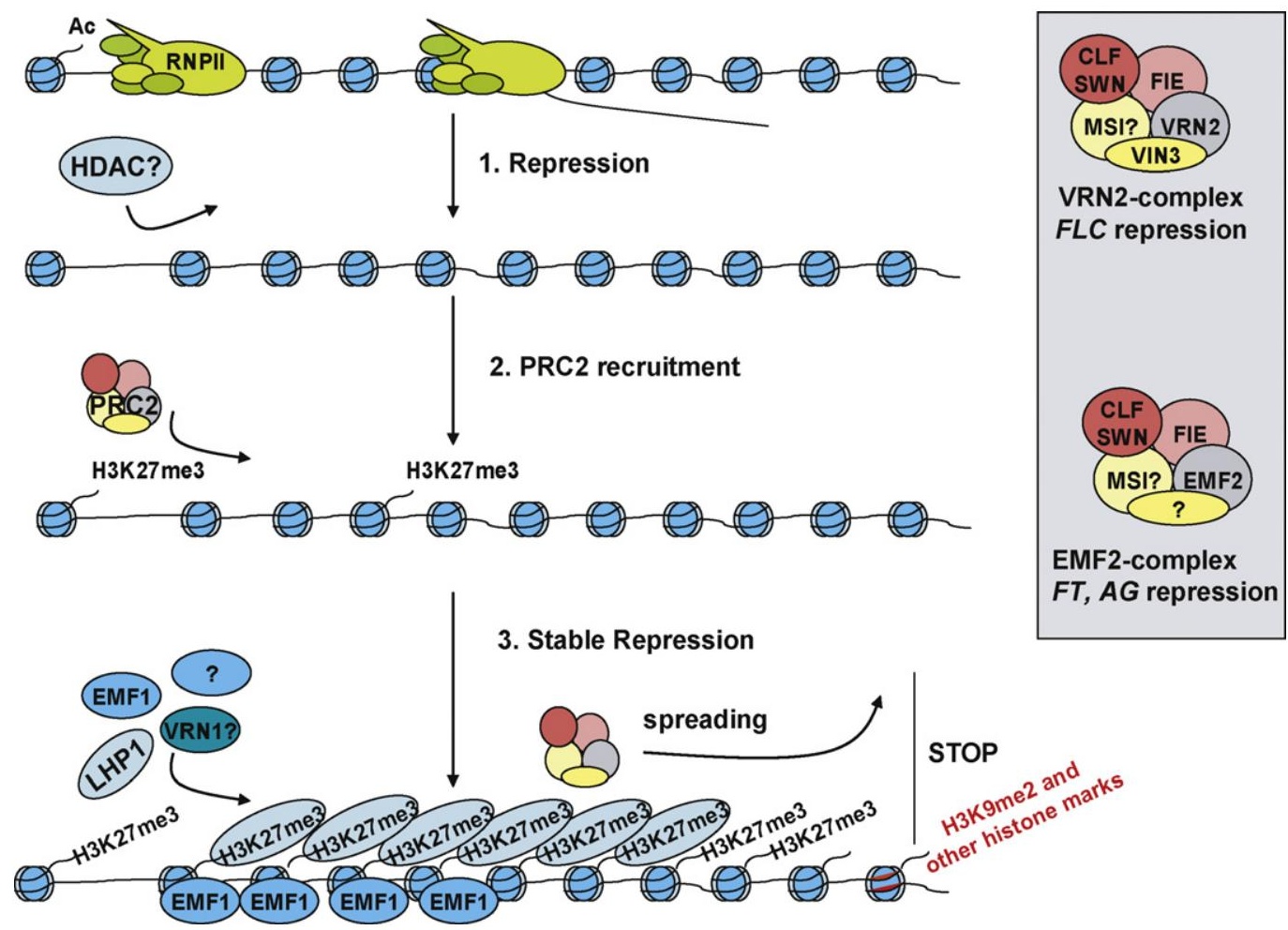

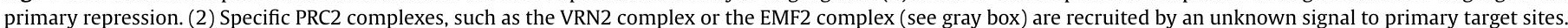

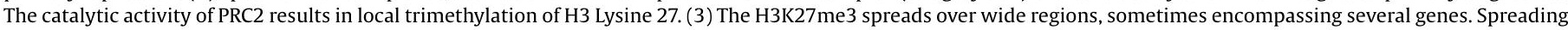

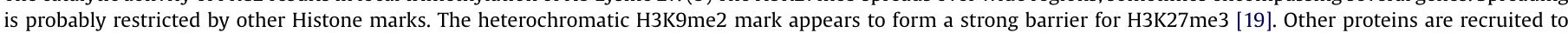

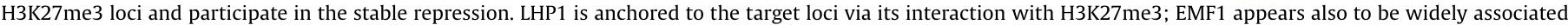
with repressed targets, whereas VRN1 may have a more gene-specific function.

Lysine 27 methylation is functionally linked to the Polycomb Group (PcG) proteins, first discovered in genetic screens for homeotic developmental mutants in Drosophila [21]. PcG proteins are found in different complexes with distinct functions. Trimethylation of lysine 27 of $\mathrm{H} 3$ is carried out by Polycomb Repressive Complex 2 (PRC2), which contains the SET-domain histone methyltransferase Enhancer of Zeste $(\mathrm{E}(\mathrm{Z})$ ) in association with Suppressor of Zeste $(\mathrm{SU}(\mathrm{Z}) 12)$ and the WD40-domain proteins Extra sex combs (ESC) and Multicopy suppressor of Ira (MSI) (SET stands for SUVAR3-9/E(Z)/Trithorax protein). H3K27me3 is recognized by PRC1, a multi-protein complex that is required for transcriptional repression. In plants, most components of the PRC2 exist as small protein families, whereas homologs of the PRC1 components are conspicuously lacking and may have been functionally replaced by unrelated proteins (Fig. 2).

\subsection{The combinatorial PRC2}

In Arabidopsis, MEDEA (MEA) [22], CURLY LEAF (CLF) [23] and SWINGER (SWN also EZA1) [24,25] encode homologs of E(Z). MEA is exclusively expressed in the gametophyte and endosperm and mutations in the gene lead to aborted development of these structures [22]. Mutations in CLF cause pleiotropic alterations in the sporophyte among which are homeotic transformations of floral organs, early flowering and altered leaf structure. Mutations in SWN alone do not cause visible alterations but enhance the effect of mea and clf mutants [24,26,27]. A decrease in H3K27me3 has been shown to occur at some genes in the clf and clf swn double mutants and this is the best experimental evidence so far of a conserved catalytic activity between the PRC2 complexes of plants and animals $[26,28]$.
Three genes encode $\mathrm{SU}(\mathrm{Z}) 12$ homologs, of which FERTILIZATION INDEPENDENT SEED 2 (FIS2) possesses gametophyte and endosperm-specific expression and is essential for seedling viability [25]. VERNALIZATION 2 (VRN2) [29] and EMBRYONIC FLOWER 2 (EMF2) [30,31] are expressed in the sporophyte and have roles that are overlapping but not identical with CLF and SWN [31,32]. Mutations in VRN2 specifically affect the vernalization pathway to flowering, whereas emf2 mutants bypass the vegetative phase of development.

FERTILIZATION INDEPENDENT ENDOSPERM (FIE) is the only gene encoding an Arabidopsis homolog of ESC. FIE is an essential gene and mutations result in embryo abortion and endosperm overproliferation [33]. FIE protein is likely to be a member of all functional PRC2 complexes in Arabidopsis.

The small gene families encoding most PRC2 proteins in plants provide a combinatorial matrix of potentially co-existing yet distinct complexes [26]. Yeast-two-hybrid experiments and more recently co-immunoprecipitation from Arabidopsis plants expressing different combinations of epitope-tagged PcG proteins confirmed the interaction between different plant PRC2 proteins and, in part, explained the differential phenotypes of respective mutations [24,34]. CLF, SWN and FIE probably each take part in many PRC2 complexes and show a more general role in plant development $[24,35,36]$. In contrast, individual $S U(Z) 12$ proteins probably have more specific roles. Therefore, a complex containing VRN2 is called the VRN2 complex and analogous EMF2 and FIS/MEA complexes have been defined [24,35,36].

In Drosophila and mammals the PRC2 also contains a MSI protein. These proteins are also part of other nuclear complexes related to chromatin regulation, such as the CHROMATIN ASSEMBLY FACTOR 1 (CAF1) or the RPD3 histone deacetylase (HDAC) complexes 
[37]. There are five MSI-like proteins in Arabidopsis of which two, MSI1 and MSI4/FVE, have been related with the regulation of flowering. MSI1 is essential for gametophyte and seed development as part of the MEA complex [38] and also plays a role as an activator of flowering through an FLC-independent pathway. However, whether MSI fulfils this function as part of a PRC2 complex remains unclear [39]. Similarly, MSI4/FVE promotes flowering through the autonomous pathway by decreasing FLC transcript levels. This protein may be part of a HDAC complex involved in the deacetylation of FLC chromatin [40]. Finally, although it is expected that one MSI protein forms part of the VRN2 complex and, therefore, plays a role in FLC regulation, so far no data have been presented that confirm this hypothesis.

\subsection{The elusive PRC 1}

Although no close homologs of PRC1 components exist in plants, genomic studies have suggested some proteins that might act as PRC1-like co-repressors. The distribution of LIKEHETEROCHROMATIN PROTEIN 1 (LHP1) to its target genes is highly correlated with H3K27me3 [19,41]. LHP1 is also termed TERMINAL FLOWER 2 (TFL2) because loss-of-function mutations cause early flowering in LD and SD, as well as the termination of the shoot in a terminal flower [42]. The correlation of LHP1 and H3K27me3 was somewhat surprising as animal HP1s typically bind lysine methylation marks of $\mathrm{H} 3$ occurring at position 9 rather than 27 and are therefore part of the SU(VAR)3-9 but not the PcG-pathway. However, LHP1 in contrast to HP1a recognizes both modifications without discrimination in vitro $[19,41]$ and exclusively correlates with H3K27me3 but not H3K9me3 or H3K9me2 in vivo [19].

HP1 family proteins are defined by the presence of two domains, the chromodomain that recognizes methyl-lysine residues and the chromoshadow domain, which is a derived chromodomain and functions as a protein-protein interaction module. The animal PRC1 complex contains the protein Polycomb (Pc) that is a chromodomain-only protein with affinity for H3K27me3. LHP1 may be part of a PRC1 analogous complex and anchor the PRC1 to H3K27me3. However, Pc is an absolute requirement for PcG repression in animals, whereas LHP1 participates in the repression of only a subset of H3K27me3 target genes. Transcriptome analysis of tfl2/lhp1 mutant plants identified only a small set of genes as upregulated compared to WT, most of which were involved in flower promoting pathways [43]. In addition, the tfl2/lhp1 phenotype is mild if compared to that of emf2, fis2, fie and clf swn [42,44].

EMF1 is a plant-specific single copy gene whose product may also be related to PRC1 function. The EMF1 protein has no conserved domains but displays a putative ATP/GTP binding motif (P-loop motif) and a LXXLL motif that it shares with other transcriptional regulators [45]. EMF1 possesses sequence-independent nucleic acid binding activity (sdDNA, ssDNA and RNA) in vitro and fragments of the protein are capable of inhibiting in vitro transcription reactions [46]. Early flowering of emf1 mutants is correlated with upregulation of genes that promote flowering such as FT, LFY, $A P 1$ and $A G$ although their precise contribution is unclear since single mutations in these genes did not suppress the early flowering phenotype of emf1 $[47,48]$. Transcriptome data show a significant overlap between genes that are misregulated in emf2 and emf1 [48] and many genes upregulated in emf 1 are also H3K27me3 targets. EMF1 and H3K27me3 co-distributed over several loci and both were shown to be dependent on EMF2 at $A G$ [46].

Although, EMF1 does not interact with EMF2, CLF and FIE [24], it physically interacts with MSI1 [46]. Since MSI1 interacts with several chromatin-related complexes it remains unclear whether EMF1 is part of the EMF2 complex or a distinct complex. In conclusion, EMF1 holds a place on the candidate list for plant-specific
PRC1 components although, like LHP1, loss of EMF1 function does not cause upregulation of all PcG targets.

\subsection{Lessons from vernalization}

The role of PcG regulation of transcription in flowering has been most extensively studied in the context of vernalization. PcG repression of FLC counteracts its activation by FRI, a plant-specific coiled-coil protein of unknown function [49]. In a vrn2 mutant the FLC gene is correctly repressed during the cold treatment, but this repression is not stable after the return of plants to normal growth temperatures [32]. Therefore, in vrn2 mutants the memory mechanism is affected but not the onset of repression. Maintenance, not establishment, of FLC repression is also dependent on $L H P 1$ [50,51] and VRN1, which was found in a screen for mutants impaired in the vernalization pathway [29]. VRN1 contains a plant-specific B3 DNA-binding domain able to interact in a non-sequence-specific way with DNA [52]. VRN1 and VRN2 do not interact in vivo which makes it unlikely that VRN1 is part of the VRN2 complex [52]. Plants overexpressing VRN1 flower earlier in SD and LD mainly due to an increase in FT expression that is independent of FLC. Therefore, VRN1 may have additional roles in flowering [52].

The PHD-domain protein VERNALIZATION INSENSITIVE 3 (VIN3) co-purifies with the VRN2 complex [36] and directly binds to the chromatin in the 5 'region of FLC (Table 1). However, in contrast to vrn1, vrn2 and lhp1 plants, vin3 mutants are compromised in their ability to downregulate FLC during vernalization [53,54]. VIN3 mRNA and protein levels increase during vernalization [36,54]. In fact, all proteins of the VRN2 complex accumulate during the cold treatment, although mRNA levels of VRN2, FIE and CLF/SWN do not change suggesting a posttranscriptional regulation of the complex at the level of protein stability [36].

Interestingly, a genomic study identified VIN3 as a potentially PcG-regulated gene because its locus is widely covered by H3K27me3 [20]. It shares the H3K27me3 mark and transcriptional upregulation during vernalization with MAF5, AGL19 and AGL24 $[5,6,55]$. The upregulation of AGL19 and AGL24 promotes flowering and occurs independently of FLC [56-58]. Interestingly, VIN3 is required for AGL19 upregulation during vernalization. VIN3 might simultaneously promote the VRN2 complex and destabilize the EMF2 complex that is thought to downregulate AGL19 in seedlings [56].

VIN3 encodes one of 5 members of the VEL gene family. Mutations in a second member of this family, VIN3 like 1/VERNALIZATION 5 (VIL1/VRN5), were recovered in two independent screens for vernalization response mutants. VIL1 physically interacts with VIN3, but its pattern of expression suggests that it has a more general role in plant development $[55,59,60]$. Interestingly, the repression of MAF1 by vernalization depends on VIN3 and VIL1, but its downregulation under SD only involves VIL1. MAF1 is not an H3K27me3 target therefore VIL1 promotes flowering through different flowering and chromatin pathways [55].

\subsection{Maintenance and resetting}

In common with PcG targets in animals FLC repression is maintained through mitosis; however, most plant H3K27me3 genes are more dynamically regulated. $F T$ is highly upregulated in emf2, clf and lhp1 mutant plants $[31,42,44,61]$, but in WT plants its expression shows little indication of mitotic memory. For example, FT transcription is immediately induced if plants are shifted from SD to LD and rapidly falls if plants are shifted back to SD [62]. In WT plants $A G$ expression is restricted to flowers and is dynamic, being expressed early in the floral primordium, followed by uniform expression in stamens and carpels, which is later restricted to a few 
Table 1

Summary of histone modifications observed at FLC

\begin{tabular}{|c|c|c|c|c|c|}
\hline Histone modification & FLC region & $\begin{array}{l}\text { Background/ } \\
\text { Arabidopsis line }\end{array}$ & $\begin{array}{l}\text { Effect during } \\
\text { vernalization }\end{array}$ & Mutant information & References \\
\hline \multirow[t]{4}{*}{ H3K9me2 } & 2,4 & Col FRI & Increase & $\begin{array}{l}\text { vin3: no increase, no } F L C \text { repression } \\
\text { vrn1: no increase, no maintenance of } F L C \text { repression } \\
\text { vrn2: as vrn1 }\end{array}$ & {$[54]$} \\
\hline & 6 & & No change & & \\
\hline & 1,2 & $\begin{array}{l}\text { Ler fca-1 } \\
\text { Ler FRI }\end{array}$ & Increase & $\begin{array}{l}\text { vrn1: no increase, no increase, no maintenance of } F L C \text { repression } \\
\text { vrn2: as } v r n 1\end{array}$ & [53] \\
\hline & 7 & Col & - & $\begin{array}{l}\text { Col: positive } \\
\text { dcl3-2: } 50 \% \text { decrease, high FLC levels }\end{array}$ & [124] \\
\hline H3K9me3 & 2,4 & Col FRI & Increase & $\begin{array}{l}\text { vin3: no increase, no FLC repression } \\
\text { vil1-1: no increase, reduced FLC repression }\end{array}$ & {$[50]$} \\
\hline \multirow[t]{3}{*}{ H3K27me2 } & 2,4 & Col FRI & Increase & $\begin{array}{l}\text { vin3: no increase, no FLC repression } \\
\text { vrn2: no increase, no maintenance of } F L C \text { repression } \\
\text { vrn1: increase, no maintenance of } F L C \text { repression }\end{array}$ & {$[54]$} \\
\hline & 6 & & No change & & \\
\hline & 2 & $\begin{array}{l}\text { Ler fca-1 } \\
\text { Ler FRI }\end{array}$ & Increase & $\begin{array}{l}\text { vrn2: no increase, no maintenance of } F L C \text { repression } \\
\text { vrn1: increase, no maintenance of } F L C \text { repression }\end{array}$ & [53] \\
\hline \multirow[t]{5}{*}{ H3K27me3 } & 2,4 & Col FRI & Increase & $\begin{array}{l}\text { vin3: no increase; no FLC repression } \\
\text { vil1-1: no increase, no FLC repression }\end{array}$ & [50] \\
\hline & 2 & Ler FRI & Increase & $\begin{array}{l}\text { vin3-6: no increase, delayed FLC repression, no maintenance of FLC } \\
\text { repression } \\
\text { vil1/vrn5-1: reduced increase, reduced and delayed FLC repression }\end{array}$ & [59] \\
\hline & $1-7$ & Ler WS? & - & ChIP-chip data & {$[19,20]$} \\
\hline & 1,2 & Col FRI & Increase & & {$[68]$} \\
\hline & $3-7$ & & $\begin{array}{l}\text { Spreading after return } \\
\text { to warm temperatures }\end{array}$ & $\begin{array}{l}\text { Mature leaves: spreading does not occur, FLC repression is not } \\
\text { maintained }\end{array}$ & \\
\hline \multirow[t]{7}{*}{ Н3К9/K14Ac } & 2,4 & Col FRI & Decrease & $\begin{array}{l}\text { vin3: no decrease, no FLC repression } \\
\text { vil1-1: as vin3 } \\
\text { vrn1: decrease but not maintained after return no warm temperatures } \\
\text { vrn2: as vrn1 }\end{array}$ & {$[50,54]$} \\
\hline & 6 & & No change & & \\
\hline & $1,2,4,5$ & $\begin{array}{l}\text { Ler fca-1 } \\
\text { Ler FRI }\end{array}$ & No change & $\begin{array}{l}\text { vrn 1: no change in fragment } 2 \\
\text { vrn2: no change in fragment } 2\end{array}$ & {$[53,59]$} \\
\hline & 3 & & Decrease & & \\
\hline & 2 & & Decrease & $\begin{array}{l}\text { vin3-6: decrease; delayed repression of FLC } \\
\text { vil1/vrn5-1: decrease; reduced repression of FLC }\end{array}$ & [59] \\
\hline & $1-7$ & Col FRI & Decrease & $\begin{array}{l}\text { Decrease not maintained after return to warm temperatures, FLC } \\
\text { repression not maintained }\end{array}$ & {$[68]$} \\
\hline & $1-7$ & Ler & - & fve: increase, high FLC levels & {$[40]$} \\
\hline \multirow[t]{2}{*}{$\mathrm{H} 4 \mathrm{~K} 5 / \mathrm{K} 8 / \mathrm{K} 12 / \mathrm{K} 16 \mathrm{Ac}$} & 2 & Col FRI & Decrease & $\begin{array}{l}\text { Mature leaves: decrease not maintained after return to warm } \\
\text { temperatures, } F L C \text { repression not maintained }\end{array}$ & {$[68]$} \\
\hline & 2 & Col & - & $\begin{array}{l}\text { fld-3: increase, high FLC levels } \\
\text { fve-4: increase, high FLC levels } \\
\text { fca-9: no change, high FLC levels } \\
\text { ld-1: no change, high FLC levels }\end{array}$ & [131] \\
\hline H2A.Z & $1-7$ & Col, Col FRI & - & $\begin{array}{l}\text { Col: peak at transcriptional start and stop arp6-1: no peak, low FLC } \\
\text { levels } \\
\text { pie1-5: no peak, low FLC levels } \\
\text { FRI: as Col, high FLC levels }\end{array}$ & [97] \\
\hline \multirow[t]{3}{*}{ H3K4me2 } & $1,2,4,5$ & $\begin{array}{l}\text { Ler fca-1 } \\
\text { Ler FRI }\end{array}$ & No change & & [53] \\
\hline & 3 & & Decrease & $\begin{array}{l}\text { vrn1: no decrease } \\
\text { vrn2: decrease }\end{array}$ & \\
\hline & 3,4 & Col & - & $\begin{array}{l}\text { fca-9: increase, high FLC levels } \\
\text { fld-3: increase, high FLC levels } \\
\text { dcl3-1: increase, high FLC levels } \\
\text { fve-3: no change, high FLC levels }\end{array}$ & [85] \\
\hline
\end{tabular}


Table 1 (Continued)

\begin{tabular}{|c|c|c|c|c|c|}
\hline Histone modification & FLC region & $\begin{array}{l}\text { Background/ } \\
\text { Arabidopsis line }\end{array}$ & $\begin{array}{l}\text { Effect during } \\
\text { vernalization }\end{array}$ & Mutant information & References \\
\hline \multirow[t]{5}{*}{ H3K4me3 } & 2 & Col FRI & Decrease & $\begin{array}{l}\text { Mature leaves: increase not maintained after return to warm } \\
\text { temperatures, FLC repression not maintained }\end{array}$ & {$[68]$} \\
\hline & 2 & Col & - & $\begin{array}{l}\text { FRI: increase, high FLC levels } \\
\text { fld3: increase; high FLC levels }\end{array}$ & {$[107]$} \\
\hline & 2 & Col FRI & - & $\begin{array}{l}\text { FRI: increase, high FLC levels } \\
\text { fca-9: Increase, high FLC levels } \\
\text { efs FRI: no increase, low FLC levels } \\
\text { efs fca: no increase, low FLC levels } \\
\text { FRI elf7-7: no increase, low FLC levels } \\
\text { FRI elf8-1: no increase, low FLC levels }\end{array}$ & {$[120]$} \\
\hline & 2 & Col & - & $\begin{array}{l}\text { ldl1 fld: Increase, high FLC } \\
\text { ldl1 ldl2: no change, high FLC levels }\end{array}$ & {$[132]$} \\
\hline & 2,3 & Col & - & $\begin{array}{l}\text { sdg8-2: no change, low FLC levels } \\
\text { sdg26-1: no change, high FLC levels } \\
\text { vip4: decrease, low FLC levels }\end{array}$ & [118] \\
\hline H3K36me1 & 2,3 & Col & - & $\begin{array}{l}\text { sdg8-2: increase, low FLC levels } \\
\text { sdg26-1: no change, high FLC levels } \\
\text { vip4: no change, low FLC levels }\end{array}$ & {$[118]$} \\
\hline \multirow[t]{3}{*}{ Н3К36me2 } & 2,3 & Col & - & $\begin{array}{l}\text { sdg8-2: decrease, low FLC levels } \\
\text { sdg26-1: no change, high FLC levels } \\
\text { vip4: decrease, low FLC levels }\end{array}$ & [118] \\
\hline & 1,4 & Col & - & sdg8-1: decrease, low FLC levels & [119] \\
\hline & 2,3 & & - & sdg8-1: no change; low FLC levels & \\
\hline Н3K36me3 & 2,3 & Col & - & $\begin{array}{l}\text { sdg8-2: decrease, low FLC levels } \\
\text { sdg26-1: no change, high FLC levels } \\
\text { vip4: decrease, low FLC levels }\end{array}$ & [118] \\
\hline FCA & 5 & Col & - & Col and 35S::FCA Chromatin factor binding & {$[85]$} \\
\hline FPA & $2,4,5$ & Col & - & 35S::FPA-YFP Chromatin factor binding & {$[125]$} \\
\hline SUF4 & 1 & Col & - & 35S::SUF4 Chromatin? factor binding & {$[147]$} \\
\hline VIN3 & 1,3 & Col & - & Chromatin factor binding & \\
\hline \multirow[t]{2}{*}{ VRN1 } & 1,3 & Col & & Chromatin factor binding & [54] \\
\hline & 1 & 2 & & 4 & \\
\hline
\end{tabular}

cells in stamens and carpels [63]. The clf mutant partially resembles an $A G$ overexpressor and shows homeotic transformations in the flowers [23], but $A G$ is normally expressed during the early stages of flower development in clf mutants and is ectopically expressed only during later stages [28]. Recent data suggest that DNA replication plays a role in mitotic maintenance of PcG repression. INCURVATA 2 (ICU2), the catalytic subunit of DNA polymerase , and LHP1 interact and in the icu2-1 mutant the H3K27me3 marked genes FT, AG, $A P 3, P I$ and SEP3 are upregulated. LHP1 shows an altered cellular localization in icu2 plants but changes in H3K27me3 were not observed at the $A G$ locus [64].

The stable repression of FLC and a few other targets (such as FWA ) may require exceptional PcG regulation. Indeed heterochromatic histone marks, such as $\mathrm{H} 3 \mathrm{~K} 27 \mathrm{me} 2$ and $\mathrm{H} 3 \mathrm{~K} 9$ me2 occur at FLC (Table 1) while DNA methylation occurs at FWA, although neither is typically correlated with H3K27me3 in plants [19]. FLC repression must be erased in the next generation and this resetting was proposed to take place during the formation of gametes or during embryo development $[65,66]$. However, meiosis is not a prerequisite for $F L C$ resetting which also occurs in various anther cell types that do not undergo meiosis [67].

"The dose alone makes the poison" (dosis sola venenum facit, Paracelsus), and therefore the density as well as the dynamics of the H3K27me3 mark needs to be considered. For example, H3K27me3 covers the whole FLC locus before vernalization $[19,20]$, but during vernalization the density of the mark increases around the transcription start site. After the return to warm temperatures this enrichment spreads over the locus in young seedlings (Table 1). In adult leaves that do not undergo cell division, the H3K27me3 increase and FLC repression during vernalization occur but both are lost after a return to warm temperatures and there is no increased spreading of H3K27me3 over the locus [68]. One possibility is that variants of $\mathrm{H} 3$ that are recalcitrant to $\mathrm{H} 3 \mathrm{~K} 27$ trimethylation [69] and expressed at higher levels in mature leaves 
are responsible for the loss of memory of the vernalization signal [68].

\section{ATP-dependent chromatin remodeling machines}

Chromatin remodeling machines (CRMs) are multi-protein complexes involved in the regulation of chromatin structure. These complexes alter histone-DNA interactions to allow a more fluid conformation that facilitates histone replacement and accessibility to the DNA. To carry out this function CRMs use the energy obtained from the hydrolysis of ATP and all purified CRMs share an ATPase/Helicase of the SWITCH 2/SUCROSE NONFERMENTING 2 (SWI2/SNF2) family as catalytic core. More than 40 SWI2/SNF2 proteins are present in Arabidopsis (www.chromdb.org) and, although no Arabidopsis CRMs have been purified yet, molecular and genetic data implicate CRMs in flowering regulation [70-72].

\subsection{PICKLE, SPLAYED and BRAHMA}

PICKLE (PKL) was the first protein of the SWI2/SNF2 family analyzed in Arabidopsis [73]. PKL forms part of the CHD-subfamily (Chromo/Helicase/DNA binding domain); furthermore, the presence of a zinc-finger domain indicates that it is an ortholog of the CHD3/Mi-2 protein of human and Drosophila, respectively [74]. CHD3/Mi-2 proteins are part of the nucleosome remodeling and histone deacetylase complex (NURD) that takes part in transcriptional repression and couples histone deacetylation with ATP-dependent chromatin remodeling and DNA methylation $[75,76]$. PKL is implicated in the GA-mediated transition from embryonic to vegetative development through repression of embryonic fate, although the pleiotropic phenotype of $p k l$ mutants indicates a more general role in development. For instance, the weak late flowering phenotype of pkl and gai (GA-insensitvie) mutants in LD conditions is strongly increased in pkl gai double mutants suggesting that PKL could play a role in the GA flowering pathway $[73,74]$.

Among the CRMs of yeast and animals, SWI/SNF complex is the best characterized. This is a 2 MD complex containing 8-11 subunits depending on the species. The core of the complex is formed by four subunits: an ATPase/Helicase of the SWI2/SNF2 subfamily, a SNF5-domain protein and two SWIRM-domain and SANT-domain proteins (SWI3). With the exception of the SNF5 homolog, each of these core and other putative subunits are encoded by small gene families in Arabidopsis, suggesting the possibility of several AtSWI/SNF complexes [71,77-81]. For instance, there are four SWI2/SNF2 ATPases/Helicases and two of them, SPLAYED (SYD) and BRAHMA (BRM), have been related with flowering [78,81]. BRM but not SYD contains a bromodomain. These domains preferentially interact with acetylated histones; however, although BRM bromodomain is able to bind histones in vitro, it does not specifically recognize this modification [82].

syd and brm mutants have pleiotropic phenotypes with only some redundant characteristics, which indicates specific and shared functions for these two proteins [78,81,83]. Mutations in syd were found as enhancers of the weak lfy-5 mutant and syd single mutants show an early inflorescence to flower transition, mainly in SDs [81]. Plants with reduced BRM expression show precocious flowering in LD and SD, whereas brm mutants flower with fewer leaves but later than WT plants under both conditions. The flowering phenotype of BRM silenced plants correlates with increased abundance of $C O, F T$ and SOC1 mRNAs, and overexpression of several flower developmental genes occurs in brm mutants. Therefore, BRM is proposed to be involved in the photoperiod pathway, although further data are needed to demonstrate its direct role $[78,79,82]$.
The SWI3 subunits have also been connected to the regulation of flowering. There are four members of this family in Arabidopsis (AtSWI3A-D) and a complex interaction network has been proposed among different AtSWI3 proteins and other components of the putative AtSWI/SNF complexes [79,80,83,84]. Loss-of-function atswi3a and atswi3b mutants are embryo lethal, but AtSWI3B is able to interact in yeast with FCA, a RNA-binding protein directly involved in the downregulation of FLC (see below) [80,85,86]. Interestingly, atswi3c and atswi3d mutants show a flowering phenotype similar to brm: slightly later flowering than WT plants, but flowering with fewer leaves, particularly in SDs. However, there is no clear correlation between the flowering phenotypes and the misregulation of flowering genes although $A P 2, A P 3, P I$ and NAP are upregulated in brm and atswic3c mutants [80]. Taken together with the fact that AtSWI3C and BRM show the strongest interaction in yeast, these two proteins could be part of a AtSWI/SNF complex that is responsible for the regulation of these flower development genes $[79,80]$.

\subsection{The SWR1 complex and the H2A.Z isoform}

PHOTOPERIOD-INDEPENDENT EARLY FLOWERING1 (PIE1) is the only member of the SWR1 subfamily of SWI2/SNF2 proteins in Arabidopsis although initially it was misclassified as an ISWI homolog (www.chromdb.org) [87]. In yeast and humans the proteins of this subfamily are the catalytic subunit of the SWR1C and SRCAP complexes, respectively; a 10-13 protein complex involved in transcriptional regulation through the replacement of $\mathrm{H} 2 \mathrm{~A}$ by the $\mathrm{H} 2 \mathrm{~A} . \mathrm{Z}$ variant [88-90] (Fig. 3). In Arabidopsis, genetic and molecular data suggest that the PIE complex also contains three proteins found in yeast SWR1C: ACTIN-RELATED PROTEIN 6 (ARP6 also SUPRESSOR OF FLC 3 (SUF3)/EARLY IN SD 1 (ESD1)), SWC6 (also SERRATED LEAVES AND EARLY FLOWERING (SEF)) and SWC2. pie, swc6 and arp6 mutants flower early in LD and SD, although they are still responsive to photoperiod. Early flowering is caused by the downregulation of FLC, MAF4 and MAF5 genes even in FRI or autonomous pathway mutant backgrounds [87,91-96]. Low FLC expression in arp6 and swc 6 mutants has been correlated with reduced acetylation of $\mathrm{H} 3$ and decreased H3K4me3 levels (Table 1), although these results do not prove a direct role of the PIE complex in the deposition of these epigenetic marks and could also be indirectly caused by FLC downregulation [94,96] (see below). The PIE complex interacts with H2A.Z, encoded by four different genes in Arabidopsis (HTA4,8,9 and 11 ; [97,98]), through PIE, ARP6 and SWC2 [92,97,99]. In addition, plants with a reduced level of general HTA expression and hta9 hta11 double mutants show a similar downregulation of FLC and its relatives and phenotypically resemble PIE complex mutants [92,99]. The H2A.Z variant is most abundant at the beginning and at the end of the transcribed region of the FLC, MAF4 and MAF5 loci, and this enrichment is markedly reduced in pie and arp6 mutants. In addition, ChIP experiments show the binding of ARP6 and SWC6 to the FLC proximal promoter region [92,97]. Taken together these results indicate that the PIE complex is involved in the deposition of H2A.Z at the FLC locus.

What is known about the role of H2A.Z in transcriptional regulation? The presence of H2A.Z has been related to repression and activation of transcription in yeast, human cells and plants; therefore, this histone variant may be preferentially associated with silent but potentially inducible genes [99-101]. Transcriptome profiling studies in pie1 and hta9 hta11 mutants show that $2 / 3$ of the genes differentially expressed in comparison to WT are upregulated, most of which are also SA responsive [97,99]. In yeast and plants many genes feature a $\sim 150 \mathrm{bp}$ nucleosome-depleted region around the transcriptional start site, which is generally 

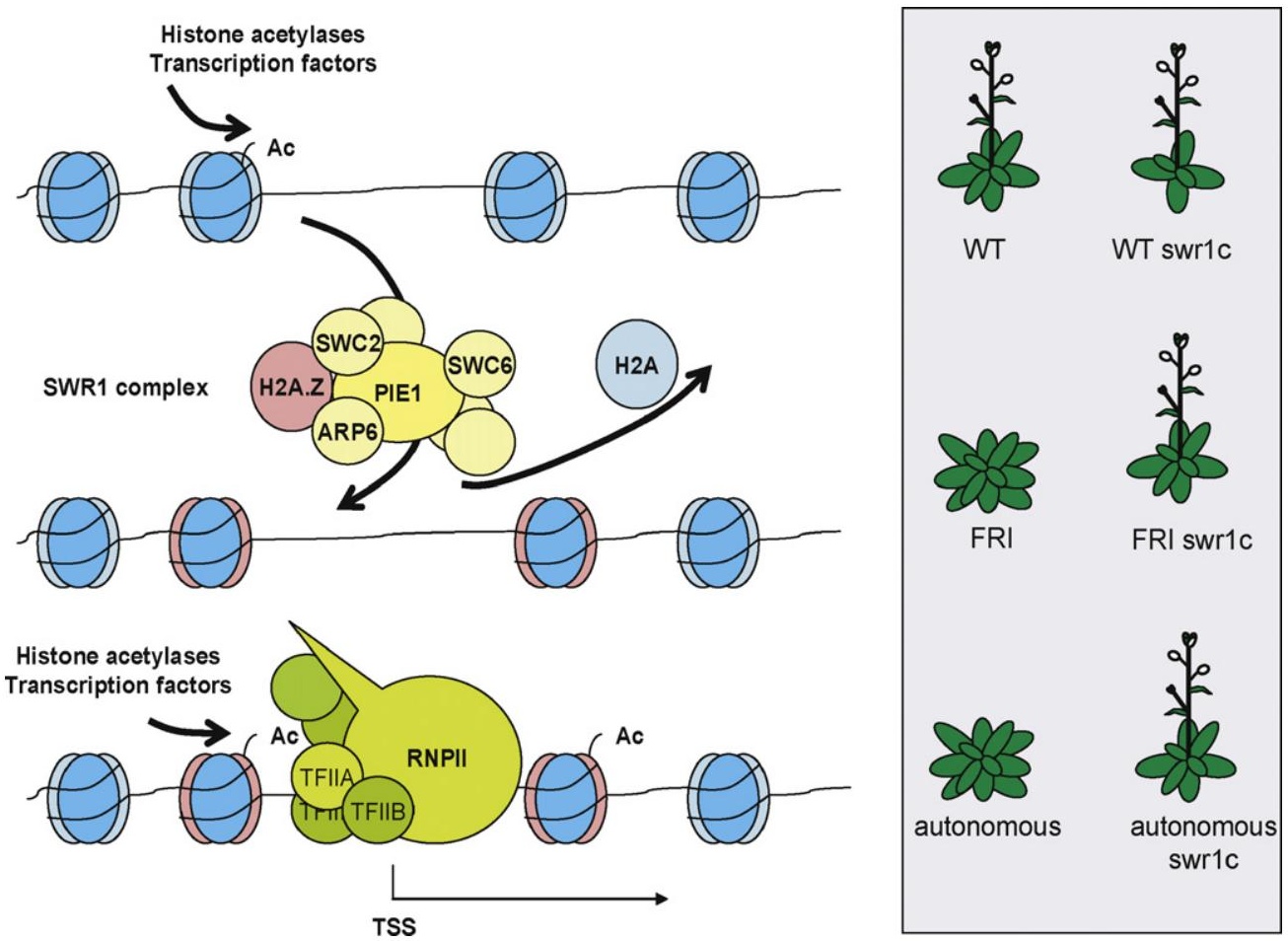

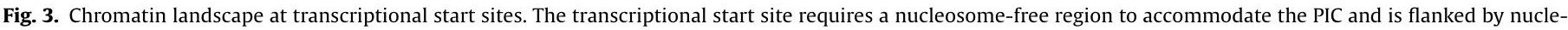

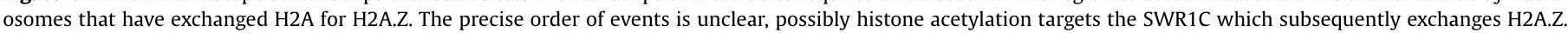

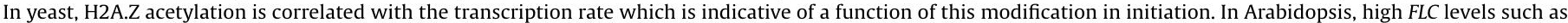

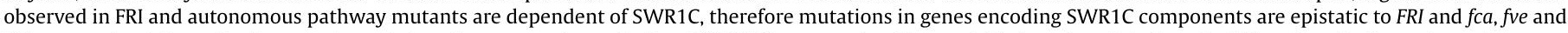
ld (see gray box). In contrast, many stress-induced genes are dependent on SWR1C for repression. The model is based on data from Arabidopsis and other eukaryotes.

flanked by one H2A.Z containing nucleosome in yeast $[20,102]$. H2A.Z is involved in the recruitment of the general transcriptional machinery and lysine 14 acetylation of H2A.Z is correlated with transcription rates in yeast [103]. However, H2A.Z in animals also correlates with specific heterochromatic regions, probably via an interaction with HP1 and Pc [104]. In contrast to other organisms, H2A.Z co-localizes exclusively with euchromatin in Arabidopsis [97,104]. In conclusion, the SWR1 complex exclusively regulates euchromatic genes in Arabidopsis, but understanding its precise participation in transcriptional activation and repression of specific genes requires further studies.

\section{The PAF1 complex and its role in transcription}

Genetic screens in high FLC expressing backgrounds for early flowering, vernalization insensitive mutants identified mutations in genes encoding 4 of the 5 subunits of the widely conserved RNPII Associated Factor 1 complex (PAF1C). The genes were designated EARLY FLOWERING (ELF) or VERNALIZATION INSENSITIVE (VIP) [105-107] and mutants in these genes show other alterations in development such as mild homeotic transformation of flower organs [108]. The severity of the abnormalities is not enhanced in double-mutants probably because deletions in one gene negatively affect accumulation of other components at the protein level. This includes the vip3 mutation [108], which may be a plant-specific addition to the PAF1C since VIP3 physically interacts with the evolutionary conserved VIP4 and VIP6 [106].

In yeast, PAF1C is recruited to RNPII during transcription initiation and persists during elongation (Fig. 4). PAF1C recruitment is dependent on Serine 5 phophorylation at the RNPII carboxy-terminal repeat domain (CTD) [18]. PAF1C orchestrates the recruitment of other complexes that participate in transcrip- tion such as histone chaperones required for the eviction and subsequent reassembly of nucleosomes on the DNA template and RAD6/Bre1 H2B-specific mono-ubiquitinase. H2B ubiquitination recruits the COMPASS complex that contains SET1 [18]. PAF1C also has an important function in transcript termination and polyadenylation (Fig. 4) [109,110].

Loss of plant PAF1C function dramatically reduces mRNA levels of FLC and this is the major although not the only cause of early flowering in the mutants $[106,107]$. Work of several groups has indicated that processes dependent on PAF1C in yeast are also important for $F L C$ regulation. High expression of FLC in a FRI background is correlated with the increase of $\mathrm{H} 3 \mathrm{~K} 4 \mathrm{me} 3$ at the $5^{\prime}$ end of the transcription cassette [107]. In yeast, H3K4 trimethylation at transcriptional start sites is dependent on SET1 which is most closely related to the Trithorax clade of SET domain proteins in plants and animals [18]. In Arabidopsis, 6 homologs designated as ARABIDOPSIS TRITHORAX (ATX) 1-6 belong to this clade; therefore, considerable gene redundancy can be expected [111,112]. Nevertheless, mutant atx1 plants flower early in SD and LD, have reduced expression levels of FLC and both effects are enhanced in a FRI background [113,114]. Furthermore, ATX1 protein directly binds to the $5^{\prime}$ end of $F L C$ and in atx 1 mutants H3K4me3 accumulation around the $5^{\prime}$ end of the gene is reduced [114].

In addition to early flowering, atx1 mutants show other developmental alterations such as slight dwarfism and defects in flower architecture [115]. In accordance with data from animals that indicate an antagonism between Trithorax SET domain and PcG proteins, some of the phenotypes observed in clf or atx 1 plants are rescued in atx 1 clf double mutants, which are less dwarfed than both parents and have normal leaves [116]. The leaf phenotype in clf is caused by ectopic expression of $A G ; A G$ is a direct target of ATX1 and, not surprisingly, ectopic $A G$ expression is reduced in clf 


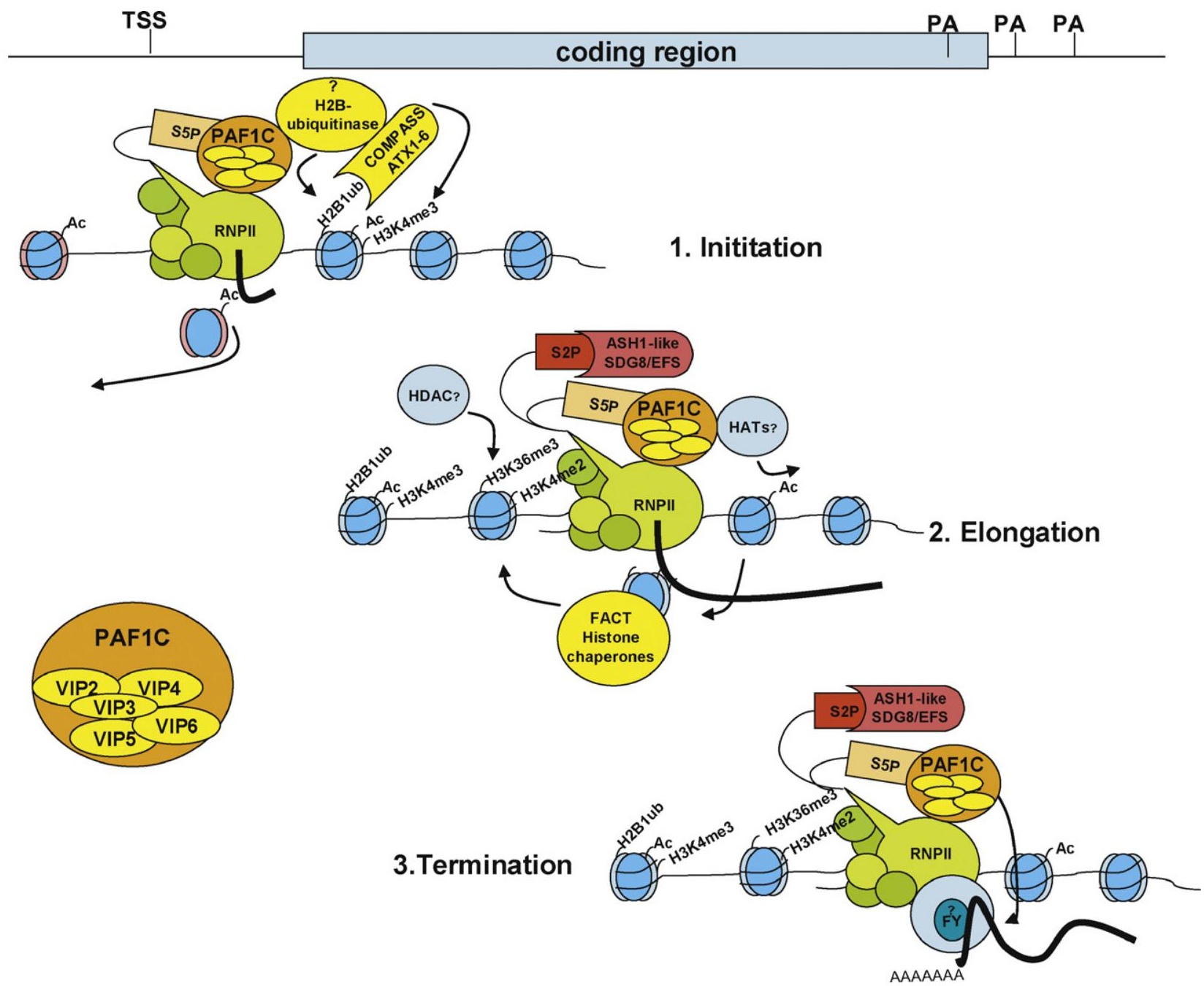

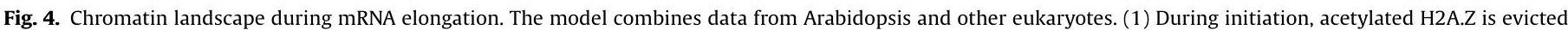

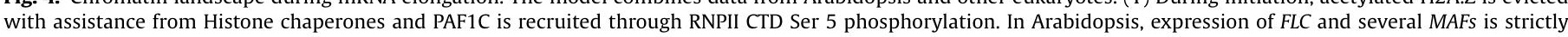

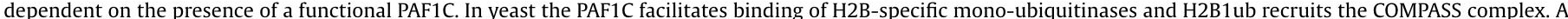

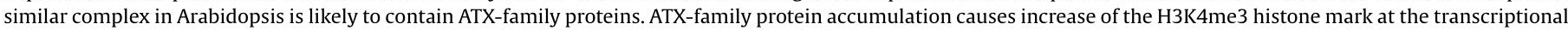

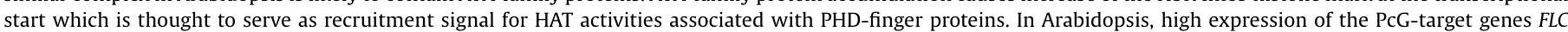

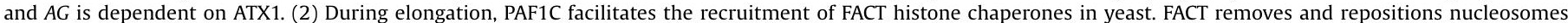

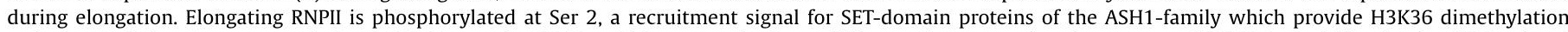

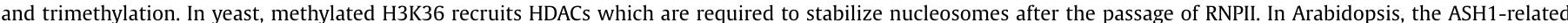

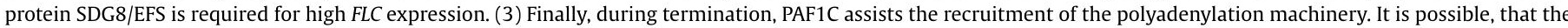
autonomous pathway component FY, a homolog of yeast polyadenylation factor pfs2p, is dependent on PAF1C in Arabidopsis.

atx1 double mutants [116]. Interestingly, CLF and ATX1 physically interact in plant cells, although the regulatory consequence of this interaction is not yet clear [116].

Similar to the amplification of the Trithorax clade, five genes encode homologs of SET2 (or ASH1 in animals) in Arabidopsis [111,112]. SET2 is recruited by Serine 2 phosphorylation at the CTD of elongating RNPII and causes dimethylation and trimethylation of $\mathrm{H3}$ lysine 36, which in turn recruits HDACs. It is still controversial, whether Serine 2 phosphorylation is dependent on PAF1C in yeast and animals $[18,117]$. Hypoacetylation of histones in actively transcribed regions is required to stabilize nucleosomes after the passage of RNPII [17,18]. Of the Arabidopsis homologs, SDG8 shows in vitro methylation activity toward $\mathrm{H} 3$ and in sdg8 mutants global H3K36me3 and H3K36me2 levels are greatly reduced [118]. The gene is identical to EARLY FLOWERING IN SHORT DAYS (EFS) and mutants display early flowering correlated with downregulation of FLC, MAF1 and MAF4 [119,120].
Surprisingly, loss of PAF1C affects the expression of only a relatively small subset of genes in Arabidopsis although the complex probably participates universally in transcription. A similar observation has been made in yeast, where the genes most dependent on PAF1C function are those most prone to use alternative polyadenylation sites [121]. Regulation of polyadeny20.9(egula3.9(ei0.9(e79pe3.9(ei0.37 


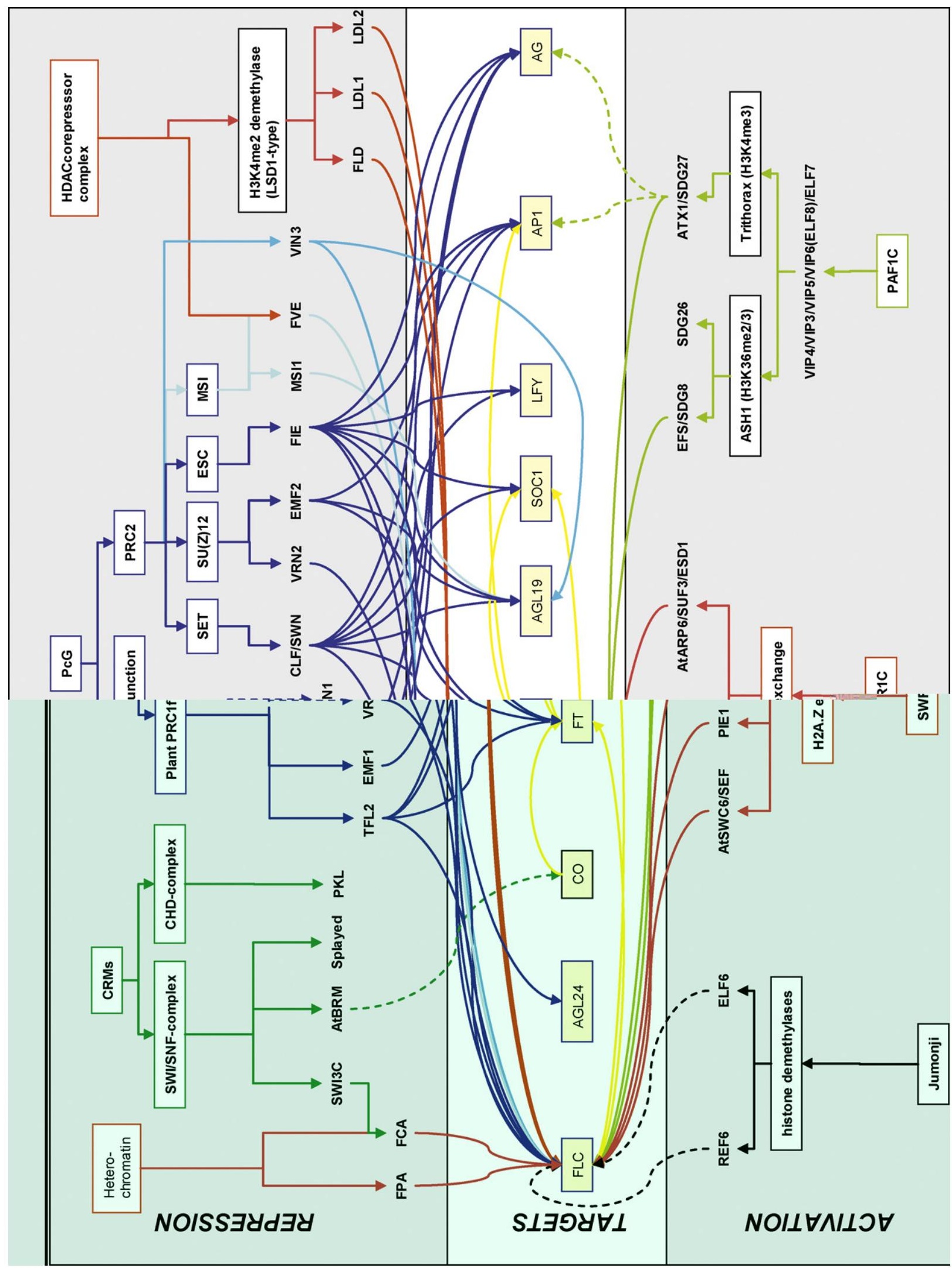

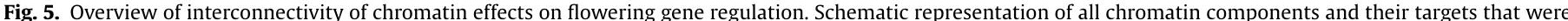

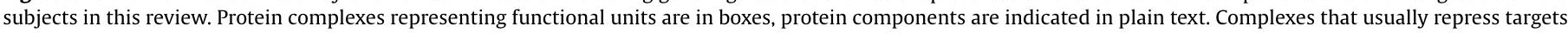

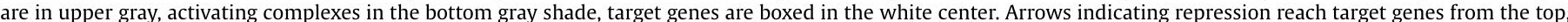

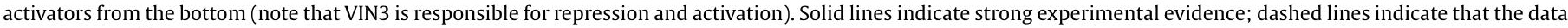
are more speculative. 
of FLC awaits further characterization and it should be noted that FCA is also thought to regulate FLC chromatin through small RNA pathways and FLD, a homolog of histone demethylase LSD1 (see below) is required for FCA function [85,125].

\section{Histone demethylating complexes}

\subsection{LSD-type histone demethylases}

Histone methylation was considered irreversible until the recent discovery of a variety of demethylating enzymes [126]. Mammalian Lysine-specific demethylase 1 ((LSD1), also K-demethylase 1 (KDM1)), is an FAD-dependent monoamine oxidase characterized by the presence of a SWIRM domain (SWI3, Rsc8p and Moira). LSD1 takes part in different complexes involved in transcriptional repression and activation, through demethylation of $\mathrm{H} 3 \mathrm{~K} 4 \mathrm{me} 2 / \mathrm{me} 1$ and H3K9me2/me1, respectively [126-130]. In metazoa LSD1 is encoded by a single-copy gene, whereas in Arabidopsis there are 4 homologs of which three are involved in flowering regulation: FLOWERING LOCUS D (FLD), LSD1-LIKE 1/SWIRM DOMAIN PAO PROTEIN 1 (LDL1/SWP1) and LSD1-LIKE 2 (LDL2) [131-133]. Some fld mutants show the strongest late flowering phenotype among the different autonomous mutants and are completely suppressed by flc. Mutations in LDL1 are late flowering in LD, whereas ldl2 enhances the late flowering phenotype of ldl1. In $l d l 1$ ldl2 plants late flowering is not completely dependent on FLC, although correlated with an increase in FLC expression [131,132]. An increase in H3K4me2 and H3K4me3 is observed at the $5^{\prime}$ region of the FLC promoter in ldl1 ldl2 and ldl1 fld double mutants, although this is surprising because LSD1 is not expected to demethylate H3K4me2. Therefore, in these mutants most H3K4me3 might become trimethylated $[126,127,132]$. In the absence of FLD, an increase in FLC promoter acetylation is observed which led to the proposal that FLD, like animal LSD1, associates with an HDAC complex $[127,131,134,135]$. The LSD1 complex also contains HISTONE METHYL TRANSFERASE (HMT) of the SET domain family [126,128] and Arabidopsis LDL1 interacts with SU(VAR)3-9-RELATED 5/C2H2 ZINC FINGER-SET DOMAIN HMT (SUVR5/CZS) in plant cells. In ldl1 and czs mutants, FLC is upregulated which is correlated with $\mathrm{H} 4$ hyperacetylation and a decrease in H3K27me2 and H3K9me2 at the $5^{\prime}$ region of $F L C$, although other groups did not detect these marks (Table 1) [132,136]. FWA, a component of the autonomous pathway is similarly regulated, but here only LDL1 and LDL2 are important for H3K4 methylation levels. Strikingly, LDL1 and LDL2 are essential for the non-CpG methylation at the tandem repeats of the FWA locus that participates in FWA silencing in the sporophyte. The results suggest a role for a relative of LSD1 in heterochromatin maintenance [132,137-139]. Despite all this circumstantial evidence, demethylase activity has not been demonstrated for any of the Arabidopsis FLD/LDL proteins, co-factors of the putative FLD/LDL complexes may be necessary for catalytic activity [132] (Fig. 5).

\subsection{Jumonji-type histone demethylases}

Jumonji (Jmj) proteins form a second class of demethylating enzymes and have been related with the regulation of many developmental features [140,141]. Jmj proteins share the conserved jmjC domain, and a majority also has at least on half of the bipartate jmjN domain consisting of a conserved jmjN motif and a DNA binding (ARID, AT-rich interaction domain) subdomain. In the last 2 years Jmj proteins involved in removing methyl groups from H3K9me3, H3K36me2 and H3K36me3, H3R2me2, H4R3me2 and H4R3me1, H3K27me2 and H3K27me3, H3K4me2 and H3K4me3 have been characterized in animals [142]. However, in Arabidop- sis only three Jmj proteins have been studied, although their enzymatic activities have not been investigated [143-145]. EARLY FLOWERING 6 (ELF6) and its closest homolog RELATIVE OF EARLY FLOWERING 6 (REF6) carry out different functions in the regulation of flowering. elf6 mutants are early flowering and this phenotype is suppressed by mutations in photoperiod pathway genes. On the other hand, ref6 mutants are late flowering in LD and SD due to FLC upregulation. High FLC expression is correlated with increased $\mathrm{H} 4$ acetylation, but as mentioned earlier this could be a secondary effect of high transcription and it does not prove a direct role for REF6 in histone acetylation. REF6 overexpressor lines also show FLC-independent upregulation of FT and SOC1; therefore REF6 could be involved in the regulation of different flowering pathways [143]. ELF6 and REF6 were also recently shown to be involved in brassinosteroid (BR)-mediated responses since they directly interact with BRI1-EMS-SUPPRESSOR 1 (BES1), a transcription factor involved in gene activation and repression in response to BRs. In elf 6 and ref6 single and double mutants some BR-regulated genes are misregulated which is correlated with an increase in H3K9me3 [145]. BR-insensitive or deficient mutants are enhancers of the autonomous pathway mutant $l d$, and this is partially due to increased FLC expression. Therefore, flowering regulation by BRs could involve the interaction between BES1 and ELF6 or REF6 to modify FLC chromatin [145,146].

\section{Conclusion}

Genetic analysis of flowering time has proven to be a sensitive method of identifying components of chromatin regulation. In particular, changes in expression of FLC are orchestrated by many aspects of chromatin regulation. The roles of chromatin regulation within the functional context of transcription are widely conserved among eukaryotes and are extensively studied in many experimental model species. This conservation allows transfer of functional information from one organism to another. However, difficulties can also arise if all aspects are assumed to be conserved. The significance of PRC1 in repressing transcription in animals and its absence from plants is a striking example of non-conservation of a functionally important complex. On the other hand, the significance of changes in histone modifications in the regulation of transcription is often unclear, because they may either be a cause or consequence of altered transcriptional states. The way ahead will need to include more plant-specific biochemical data to complement the genetic information.

\section{References}

[1] Kobayashi Y, Weigel D. Move on up, it's time for change-mobile signals controlling photoperiod-dependent flowering. Genes Dev 2007;21(19):2371-84

[2] Turck F, Fornara F, Coupland G. Regulation and identity of florigen: FLOWERING LOCUS T moves center stage. Annu Rev Plant Biol 2008;59:573-94.

[3] Helliwell CA, Wood CC, Robertson M, Peacock JW, Dennis ES. The Arabidopsis FLC protein interacts directly in vivo with SOC1 and FT chromatin and is part of a high-molecular-weight protein complex. Plant J 2006;46(2):183-92.

[4] Searle I, He Y, Turck F, Vincent C, Fornara F, Krober S. The transcription factor FLC confers a flowering response to vernalization by repressing meristem competence and systemic signaling in Arabidopsis. Genes Dev 2006;20(7):898-912

[5] Ratcliffe OJ, Kumimoto RW, Wong BJ, Riechmann JL. Analysis of the Arabidopsis MADS AFFECTING FLOWERING gene family: MAF2 prevents vernalization by short periods of cold. Plant Cell 2003;15(5):1159-69.

[6] Ratcliffe OJ, Nadzan GC, Reuber TL, Tiechmann JL. Regulation of flowering in Arabidopsis by an FLC homologue. Plant Physiol 2001;126(1):122-32.

[7] Scortecci KC, Michaels SD, Amasino RM. Identification of a MADS-box gene, FLOWERING LOCUS M, that represses flowering. Plant J 2001;26(2):229-36.

[8] Alexandre CM, Hennig L. FLC or not FLC: the other side of vernalization. J Exp Bot 2008;59(6):1127-35.

[9] Schmitz RJ, Amasino RM. Vernalization: a model for investigating epigenetics and eukaryotic gene regulation in plants. Biochim Biophys Acta 2007; 1769(5/6):269-75. 
[10] Baurle I, Dean C. The timing of developmental transitions in plants. Cell 2006;125(4):655-64.

[11] Dennis ES, Peacock WJ. Epigenetic regulation of flowering. Curr Opin Plant Biol 2007;10(5):520-7.

[12] Michaels SD, Ditta G, Gustafson-Brown C, Pelaz S, Yanofsky M, Amasino RM. AGL24 acts as a promoter of flowering in Arabidopsis and is positively regulated by vernalization. Plant J 2003;33(5):867-74.

[13] Lee J, Oh M, Park H, Lee I. SOC1 translocated to the nucleus by interaction with AGL24 directly regulates LEAFY. Plant J 2008;55(5):832-43.

[14] Liu C, Chen H, Er HL, Soo HM, Kumar PP, Han JH, et al. Direct interaction of AGL24 and SOC1 integrates flowering signals in Arabidopsis. Development 2008;135(8):1481-91.

[15] Lee JH, Yoo SJ, Park SH, Hwang I, Lee JS, Ahn JH. Role of SVP in the control of flowering time by ambient temperature in Arabidopsis. Genes Dev 2007;21(4):397-402.

[16] Luger K, Mader AW, Richmond RK, Sargent DF, Richmont TJ. Crystal structure of the nucleosome core particle at $2.8 \mathrm{~A}$ resolution. Nature 1997;389(6648):251-60.

[17] Thiriet $C$, Hayes JJ. Histone dynamics during transcription: exchange of $\mathrm{H} 2 \mathrm{~A} / \mathrm{H} 2 \mathrm{~B}$ dimers and H3/H4 tetramers during pol II elongation. Results Probl Cell Differ 2006;41:77-90.

[18] Kulaeva OI, Gaykalova DA, Studitsky VM. Transcription through chromatin by RNA polymerase II: histone displacement and exchange. Mutat Res 2007;618(1/2):116-29.

[19] Turck F, Roudier F, Farrona S, Martin-Magniette ML, Guillaume E, Buisine N, et al. Arabidopsis TFL2/LHP1 specifically associates with genes marked by trimethylation of histone H3 lysine 27. PLoS Genet 2007;3(6):e86.

[20] Zhang X, Clarenz O, Cokus S, Bernatavichute YV, Pellegrini M, Goodrich J, et al. Whole-genome analysis of histone $\mathrm{H} 3$ lysine 27 trimethylation in Arabidopsis. PLoS Biol 2007;5(5):e129.

[21] Schwartz YB, Pirrotta V. Polycomb silencing mechanisms and the management of genomic programmes. Nat Rev Genet 2007;8(1):9-22.

[22] Grossniklaus U, Vielle-Calzada JP, Hoeppner MA, Gagliano WB. Maternal control of embryogenesis by MEDEA, a Polycomb Group gene in Arabidopsis. Science 1998;280(5362):446-50.

[23] Goodrich J, Puangsomlee P, Martin M, Long D, Meyerowitz EM, Coupland G. A polycomb-group gene regulates homeotic gene expression in Arabidopsis. Nature 1997;386(6620):44-51.

[24] Chanvivattana Y, Bishopp A, Schubert D, Stock C, Moon YH, Sung ZR, et al. Interaction of polycomb-group proteins controlling flowering in Arabidopsis Development 2004;131(21):5263-76

[25] Luo M, Bilodeau P, Dennis ES, Peacock WJ, Chaudhury A. Expression and parent-of-origin effects for FIS2, MEA and FIE in the endosperm and embryo of developing Arabidopsis seeds. Proc Natl Acad Sci USA 2000;97(19):10637-42.

[26] Makarevich G, Leroy O, Akinci U, Schubert D, Clarenz O, Goodrich J, et al. Different Polycomb Group complexes regulate common target genes in Arabidopsis. EMBO Rep 2006;7(9):947-52.

[27] Wang D, Tyson MD, Jackson SS, Yadegary R. Partially redundant functions of two SET-domain polycomb-group proteins in controlling initiation of seed development in Arabidopsis. Proc Natl Acad USA 2006;103(35): 13244-9.

[28] Schubert D, Primavesi L, Bishopp A, Roberts G, Doonan J, Jenuwein T, et al. Silencing by plant polycomb-group genes requires dispersed trimethylation of histone $\mathrm{H} 3$ at lysine 27. EMBO J 2006;25(19):4638-49.

[29] Chandler J, Wilson A, Dean C. Arabidopsis mutants showing an altered response to vernalization. Plant J 1996;10(4):637-44.

[30] Yang CH, Chen LJ, Sung ZR. Genetic regulation of shoot development in Arabidopsis: role of the EMF genes. Dev Biol 1995;169(2):421-35.

[31] Yoshida N, Yanai Y, Chen L, Kato Y, Hiratsuka J, Miwa T, et al. EMBRYONIC FLOWER2, a novel Polycomb Group protein homolog, mediates shoot development and flowering in Arabidopsis. Plant Cell 2001;13(11):2471-81.

[32] Gendall AR, Levy YY, Wilson A, Dean C. The VERNALIZATION 2 gene mediates the epigenetic regulation of vernalization in Arabidopsis. Cell 2001;107(4):525-35.

[33] Ohad N, Yadegari R, Margossian L, Hannon M, Michaeli D, Harada JJ, et al. Mutations in FIE, a WD Polycomb Group gene, allow endosperm development without fertilization. Plant Cell 1999;11(3):407-16.

[34] Katz A, Oliva M, Mosquna A, Hakim O, Ohad N. FIE and CURLY LEAF polycomb proteins interact in the regulation of homeobox gene expression during sporophyte development. Plant J 2004;37(5):707-19.

[35] Kohler C, Grossniklaus U. Epigenetic inheritance of expression states in plan development: the role of Polycomb Group proteins. Curr Opin Cell Bio 2002;14(6):773-9.

[36] Wood CC, Robertson M, Tanner G, Peacock WJ, Dennis ES, Helliwell CA. The Arabidopsis thaliana vernalization response requires a polycomb-like protein complex that also includes VERNALIZATION INSENSITIVE 3. Proc Natl Acad Sci USA 2006;103:14631-6.

[37] Hennig L, Bouveret R, Gruissem W. MSI1-like proteins: an escort service for chromatin assembly and remodeling complexes. Trends Cell Bio 2005;15(6):295-302.

[38] Kohler C, Hennig L, Bouveret R, Gheyselinck J, Grossniklaus U, Gruissem W. Arabidopsis MSI1 is a component of the MEA/FIE Polycomb Group complex and required for seed development. EMBO J 2003;22(18):4804-14.

[39] Bouveret R, Schonrock N, Gruissem W, Hennig L. Regulation of flowering time by Arabidopsis MSI1. Development 2006;133(9):1693-702.
[40] Ausin I, Alonso-Blanco C, Jarillo JA, Ruiz-Garcia L, Martinez-Zapater JM. Regulation of flowering time by FVE, a retinoblastoma-associated protein. Nat Genet 2004;36(2):162-6.

[41] Zhang X, Germann S, Blus BJ, Khorasanizadeh S, Gaudin V, Jacobsen SE. The Arabidopsis LHP1 protein colocalizes with histone H3 Lys27 trimethylation. Nat Struct Mol Biol 2007;14(9):869-71.

[42] Kotake T, Takada S, Nakahigashi K, Ohto M, Goto K. Arabidopsis TERMINAL FLOWER 2 gene encodes a heterochromatin protein 1 homolog and represses both FLOWERING LOCUS $\mathrm{T}$ to regulate flowering time and several floral homeotic genes. Plant Cell Physiol 2003;44(6):555-64.

[43] Nakahigashi K, Jasencakova Z, Schubert I, Goto K. The Arabidopsis heterochromatin protein1 homolog (TERMINAL FLOWER2) silences genes within the euchromatic region but not genes positioned in heterochromatin. Plant Cell Physiol 2005;46(11):1747-56.

[44] Gaudin V, Libault M, Pouteau S, Juul T Zhao G, Lefebvre D et al Mutations in LIKE HETEROCHROMATIN PROTEIN 1 affect flowering time and plant architecture in Arabidopsis. Development 2001;128(23):4847-58.

[45] Aubert D, Chen L, Moon YH, Martin D, Castle LA, Yang CH, et al. EMF1, a novel protein involved in the control of shoot architecture and flowering in Arabidopsis. Plant Cell 2001;13(8):1865-75.

[46] Calonje M, Sanchez R, Chen L, Sung ZR. EMBRYONIC FLOWER1 participates in Polycomb Group-mediated AG gene silencing in Arabidopsis. Plant Cell 2008;20(2):277-91.

[47] Chou ML, Haung MD, Yang CH. EMF genes interact with late-flowering genes in regulating floral initiation genes during shoot development in Arabidopsis thaliana. Plant Cell Physiol 2001;42(5):499-507.

[48] Moon YH, Chen L, Pan RL, Chang HS, Zhu T, Maffeo DM, et al. EMF genes maintain vegetative development by repressing the flower program in Arabidopsis. Plant Cell 2003;15(3):681-93.

[49] Johanson U, West J, Lister C, Michaels S, Amasino R, Dean C. Molecular analysis of FRIGIDA, a major determinant of natural variation in Arabidopsis flowering time. Science 2000;290(5490):344-7.

[50] Sung S, He Y, Eshoo TW, Tamada Y, Johnson L, Nakahigashi K. Epigenetic maintenance of the vernalized state in Arabidopsis thaliana requires LIKE HETEROCHROMATIN PROTEIN 1. Nat Genet 2006;38(6):706-10

[51] Mylne JS, Barrett L, Tessadori F, Mesnage S, Johnson L, Bernatavichute YV, et al. LHP1, the Arabidopsis homologue of HETEROCHROMATIN PROTEIN1, is required for epigenetic silencing of FLC. Proc Natl Acad Sci USA 2006;103(13):5012-7.

[52] Levy YY, Mesnage S, Mylne JS, Gendall AR, Dean C. Multiple roles of Arabidopsis VRN1 in vernalization and flowering time control. Science 2002;297(5579):243-6

[53] Bastow R, Mylne JS, Listeer C, Lippmann Z, Martienssen RA, Dean C. Vernalization requires epigenetic silencing of FLC by histone methylation. Nature 2004;427(6970):164-7.

[54] Sung S, Amasino RM. Vernalization in Arabidopsis thaliana is mediated by the PHD finger protein VIN3. Nature 2004;427(6970):159-64.

[55] Sung S, Schmitz RJ, Amasino RM. A PHD finger protein involved in both the vernalization and photoperiod pathways in Arabidopsis. Genes Dev 2006;20(23):3244-8.

[56] Schonrock N, Bouveret R, Leroy O, Borghi L, Kohler C, Gruissem W., et al. Polycomb-group proteins repress the floral activator AGL19 in the FLCindependent vernalization pathway. Genes Dev 2006;20(12):1667-78.

[57] Michaels SD, He Y, Scortecci KC, Amasino RM. Attenuation of FLOWERING LOCUS C activity as a mechanism for the evolution of summer-annual flowering behavior in Arabidopsis. Proc Natl Acad Sci USA 2003;100(17):10102-7.

[58] Yu H, Xu Y, Tan EL, Kumar PP. AGAMOUS-LIKE 24, a dosage-dependent mediator of the flowering signals. Proc Natl Acad Sci USA 2002;99(25):16336-41.

[59] Greb T, Mylne JS, Crevillen P, Geraldo N, An H, Gendall AR, et al. The PHD finger protein VRN5 functions in the epigenetic silencing of Arabidopsis FLC. Curr Biol 2007:17(1):73-8.

[60] Mylne J, Greb T, Lister C, Dean C. Epigenetic regulation in the control of flowering. Cold Spring Harb Symp Quant Biol 2004;69:457-64.

[61] Kinoshita T, Greb T, Lister C, Dean C. Polycomb repression of flowering during early plant development. Proc Natl Acad Sci USA 2001;98(24):14156-61.

[62] Corbesier L, Vincent C, Jang S, Fornara F, Fan Q, Searle I, et al. FT protein movement contributes to long-distance signaling in floral induction of Arabidopsis. Science 2007;316(5827):1030-3.

[63] Bowman JL, Drews GN, Meyerowitz EM. Expression of the Arabidopsis floral homeotic gene AGAMOUS is restricted to specific cell types late in flower development. Plant Cell 1991;3(8):749-58.

[64] Barrero JM, Gonzalez-Bayon R, del Pozo JC, Ponce MR, Micol JL. INCURVATA2 encodes the catalytic subunit of DNA Polymerase alpha and interacts with genes involved in chromatin-mediated cellular memory in Arabidopsis thaliana. Plant Cell 2007;19(9):2822-38.

[65] Boss PK, Bastow RM, Mylne JS, Dean C. Multiple pathways in the decision to flower: enabling, promoting, and resetting. Plant Cell 2004;16(Suppl.):S18-31.

[66] Henderson IR, Dean C. Control of Arabidopsis flowering: the chill before the bloom. Development 2004;131(16):3829-38.

[67] Sheldon CC, Hills MJ, Lister C, Dean C, Dennis ES, Peacock WJ. Resetting of FLOWERING LOCUS C expression after epigenetic repression by vernalization. Proc Natl Acad Sci USA 2008;105(6):2214-9.

[68] Finnegan EJ, Dennis ES. Vernalization-induced trimethylation of histone $\mathrm{H3}$ lysine 27 at FLC is not maintained in mitotically quiescent cells. Curr Biol 2007;17(22):1978-83. 
[69] Johnson L, Mollah S, Garcia BA, Muratore TL, Shabanowitz J, Hunt DF, et al. Mass spectrometry analysis of Arabidopsis histone $\mathrm{H} 3$ reveals distinct combinations of post-translational modifications. Nucleic Acids Res 2004;32(22):6511-8.

[70] Jerzmanowski A.SWI/SNF chromatin remodeling and linker histones in plants. Biochim Biophys Acta 2007;1769(5/6):330-45.

[71] Kwon CS, Wagner D. Unwinding chromatin for development and growth: a few genes at a time. Trends Genet 2007;23(8):403-12.

[72] Saha A, Wittmeyer J, Cairns BR. Chromatin remodelling: the industrial revolution of DNA around histones. Nat Rev Mol Cell Biol 2006;7(6):437-47.

[73] Ogas J, Cheng JC, Sung ZR, Somerville C. Cellular differentiation regulated by gibberellin in the Arabidopsis thaliana pickle mutant. Science 1997;277(5322):91-4

[74] Ogas J, Kaufmann S, Henderson J, Somerville C. PICKLE is a CHD3 chromatinremodeling factor that regulates the transition from embryonic to vegetative development in Arabidopsis. Proc Natl Acad Sci USA 1999;96(24):13839-44.

[75] Hall JA, Georgel PT. CHD proteins: a diverse family with strong ties. Biochem Cell Biol 2007;85(4):463-76.

[76] Marfella CG, Imbalzano AN. The Chd family of chromatin remodelers. Mutat Res 2007;618(1/2):30-40.

[77] Brzeski J, Podstolski W, Olczak K, Jerzmanowski A. Identification and analysis of the Arabidopsis thaliana BSH gene, a member of the SNF5 gene family. Nucleic Acids Res 1999;27(11):2393-9.

[78] Farrona S, Hurtado L, Bowman JL, Reyes JC. The Arabidopsis thaliana SNF2 homolog AtBRM controls shoot development and flowering. Development 2004;131(20):4965-75.

[79] Hurtado L, Farrona S, Reyes JC. The putative SWI/SNF complex subunit BRAHMA activates flower homeotic genes in Arabidopsis thaliana. Plant Mol Biol 2006;62(1/2):291-304.

[80] Sarnowski TJ, Rios G, Jasik J, Swiezewski S, Kaczanowski S, Li Y, et al. SWI3 subunits of putative SWI/SNF chromatin-remodeling complexes play distinct roles during Arabidopsis development. Plant Cell 2005;17(9):2454-72.

[81] Wagner D, Meyerowitz EM. SPLAYED, a novel SWI/SNF ATPase homolog, controls reproductive development in Arabidopsis. Curr Biol 2002;12(2):85-94.

[82] Farrona S, Hurtado L, Reyes JC. A nucleosome interaction module is required for normal function of Arabidopsis thaliana BRAHMA. J Mol Biol 2007:373(2):240-50.

[83] Bezhani S, Winter C, Hershman S, Wagner JD, Kennedy JF, Kwon CS, et al. Unique, shared, and redundant roles for the Arabidopsis SWI/SNF chromatin remodeling ATPases BRAHMA and SPLAYED. Plant Cell 2007;19(2):403-16.

[84] Sarnowski TJ, Swiezewski S, Pawlikowska K, Kaczanowski S, Jerzmanowski A. AtSWI3B, an Arabidopsis homolog of SWI3, a core subunit of yeast Swi/Snf chromatin remodeling complex, interacts with FCA, a regulator of flowering time. Nucleic Acids Res 2002;30(15):3412-21.

[85] Liu F, Quesada V, Crevillen P, Baurle I, Swiezewski S, Dean C. The Arabidopsis RNA-binding protein FCA requires a lysine-specific demethylase 1 homolog to downregulate FLC. Mol Cell 2007;28(3):398-407.

[86] Macknight R, Bancroft I, Page T, Lister C, Schmidt R, Love K, et al. FCA, a gene controlling flowering time in Arabidopsis, encodes a protein containing RNAbinding domains. Cell 1997;89(5):737-45.

[87] Noh YS, Amasino RM. PIE1, an ISWI family gene, is required for FLC activation and floral repression in Arabidopsis. Plant Cell 2003;15(7):1671-82.

[88] Cai Y, Jin J, Florens L, Swanson SK, Kusch T, Li B, et al. The mammalian YL1 protein is a shared subunit of the TRRAP/TIP60 histone acetyltransferase and SRCAP complexes. J Biol Chem 2005;280(14):13665-70.

[89] Krogan NJ, Keogh MC, Datta N, Sawa C, Ryan OW, Ding H, et al. A Snf2 family ATPase complex required for recruitment of the histone H2A variant Htz1. Mol Cell 2003;12(6):1565-76.

[90] Mizuguchi G, Shen X, Landry J, Wu WH, Sen S, Wu C. ATP-driven exchange of histone H2AZ variant catalyzed by SWR1 chromatin remodeling complex. Science 2004;303(5656):343-8.

[91] Choi K, Kim S, Kim SY, Kim M, Hyun Y, Lee H, et al. Suppressor of FRIGIDA3 encodes a nuclear ACTIN-RELATED PROTEIN6 required for floral repression in Arabidopsis. Plant Cell 2005;17(10):2647-60.

[92] Choi K, Park C, Lee J, Oh M, Noh B, Lee I. Arabidopsis homologs of components of the SWR1 complex regulate flowering and plant development. Development 2007;134(10):1931-41.

[93] Deal RB, Kandasamy MK, McKinney EC, Meagher RB. The nuclear actin-related protein ARP6 is a pleiotropic developmental regulator required for the maintenance of FLOWERING LOCUS C expression and repression of flowering in Arabidopsis. Plant Cell 2005;17(10):2633-46.

[94] Lazaro A, Gomez-Zambrano A, Lopez-Gonzalez L, Pineiro M, Jarillo JA. Mutations in the Arabidopsis SWC6 gene, encoding a component of the SWR1 chromatin remodelling complex, accelerate flowering time and alter leaf and flower development. J Exp Bot 2008;59(3):653-66.

[95] March-Diaz R, Garcia-Dominguez M, Florencio FJ, Reyes JC. SEF, a new protein required for flowering repression in Arabidopsis, interacts with PIE1 and ARP6. Plant Physiol 2007;143(2):893-901.

[96] Martin-Trillo M, Lazaro A, Poethig RS, Gomez-Mena C, Pineiro MA, MartinezZapater JM, et al. EARLY IN SHORT DAYS 1 (ESD1) encodes ACTIN-RELATED PROTEIN 6 (AtARP6), a putative component of chromatin remodelling complexes that positively regulates FLC accumulation in Arabidopsis. Development 2006;133(7):1241-52.

[97] Deal RB, Topp CN, McKinney EC, Meagher RB. Repression of flowering in Arabidopsis requires activation of FLOWERING LOCUS C expression by the histone variant H2A.Z. Plant Cell 2007;19(1):74-83.
[98] Yi H, Sardesai N, Fujinuma T, Chan CW, Veena, Gelvin SB. Constitutive expression exposes functional redundancy between the Arabidopsis histone H2A gene HTA1 and other H2A gene family members. Plant Cel 2006;18(7):1575-89.

[99] March-Diaz R, Garcia-Dominguez M, Lozano-Juste J, Leon J, Florencio FJ Reyes JC. Histone H2A.Z and homologues of components of the SWR1 complex are required to control immunity in Arabidopsis. Plant J 2008;53(3): 475-87.

[100] Guillemette B, Gaudreau L. Reuniting the contrasting functions of H2A.Z. Biochem Cell Biol 2006;84(4):528-35.

[101] Raisner RM, Madhani HD. Patterning chromatin: form and function for H2A.Z variant nucleosomes. Curr Opin Genet Dev 2006;16(2):119-24.

[102] Yuan GC, Liu YJ, Dion MF, Slack MD, Wu LF, Altschuler SJ, et al. Genome-scale identification of nucleosome positions in $S$. cerevisiae. Science 2005;309(5734):626-30.

[103] Millar CB, Xu F, Zhang K, Grunstein M. Acetylation of H2AZ Lys 14 is associated with genome-wide gene activity in yeast. Genes Dev 2006;20(6): $711-22$.

[104] Kamakaka RT, Biggins S. Histone variants: deviants? Genes Dev 2005;19(3): 295-310.

[105] Zhang H, van Nocker S. The VERNALIZATION INDEPENDENCE 4 gene encodes a novel regulator of FLOWERING LOCUS C. Plant J 2002;31(5):663-73.

[106] Oh S, Zhang H, Ludwig P, van Nocker S. A mechanism related to the yeast transcriptional regulator Paf1c is required for expression of the Arabidopsis FLC/MAF MADS box gene family. Plant Cell 2004;16(11):2940-53.

[107] He Y, Doyle MR, Amasino RM. PAF1-complex-mediated histone methylation of FLOWERING LOCUS C chromatin is required for the vernalizationresponsive, winter-annual habit in Arabidopsis. Genes Dev 2004;18(22) 2774-84.

[108] Zhang H, Ransom C, Ludwig P, van Nocker S. Genetic analysis of early flowering mutants in Arabidopsis defines a class of pleiotropic developmental regulator required for expression of the flowering-time switch flowering locus $\mathrm{C}$. Genetics 2003;164(1):347-58.

[109] Chaudhary K, Deb S, Moniaux N, Ponnusamy MP, Batra SK. Human RNA polymerase II-associated factor complex: dysregulation in cancer. Oncogene 2007;26(54):7499-507.

[110] Rosonina E, Manley JL. From transcription to mRNA: PAF provides a new path. Mol Cell 2005;20(2):167-8

[111] Baumbusch LO, Thorstensen T, Krauss V, Fischer A, Naumann K, Assalkhou R, et al. The Arabidopsis thaliana genome contains at least 29 active genes encoding SET domain proteins that can be assigned to four evolutionarily conserved classes. Nucleic Acids Res 2001;29(21):4319-33.

[112] Springer NM, Napoli CA, Selinger DA, Pandey R, Cone KC, Chandler VL, et al. Comparative analysis of SET domain proteins in maize and Arabidopsis reveals multiple duplications preceding the divergence of monocots and dicots. Plant Physiol 2003;132(2):907-25.

[113] Saleh A, Alvarez-Venegas R, Yilmaz M, Le O, Hou G, Sadder M, et al The highly similar Arabidopsis homologs of Trithorax ATX1 and ATX2 encode proteins with divergent biochemical functions. Plant Cell 2008;20: 568-79.

[114] Pien S, Fleury D, Mylne JS, Crevillen P, Inze D, Avramova Z, et al. ARABIDOPSIS TRITHORAX1 dynamically regulates FLOWERING LOCUS C activation via Histone 3 Lysine 4 trimethylation. Plant Cell 2008;20:580-8.

[115] Alvarez-Venegas R, Pien S, Sadder M, Witmer X, Grossniklaus U, Avramova Z ATX-1, an Arabidopsis homolog of trithorax, activates flower homeotic genes. Curr Biol 2003;13(8):627-37.

[116] Saleh A, Al-Abdallat A, Ndamukong I, Alvarez-Venegas R, Avramova Z. The Arabidopsis homologs of trithorax (ATX1) and enhancer of zeste (CLF) establish 'bivalent chromatin marks' at the silent AGAMOUS locus. Nucleic Acids Res 2007;35(18):6290-6.

[117] Workman JL. Nucleosome displacement in transcription. Genes Dev 2006;20(15):2009-17.

[118] Xu L, Zhao Z, Dong A, Soubigou-Taconnat L, Renou JP, Steinmetz A, et al. Diand tri- but not monomethylation on histone $\mathrm{H} 3$ lysine 36 marks active transcription of genes involved in flowering time regulation and other processes in Arabidopsis thaliana. Mol Cell Biol 2008;28(4):1348-60.

[119] Zhao Z, Yu Y, Meyer D, Wu C, Shen WH. Prevention of early flowering by expression of FLOWERING LOCUS C requires methylation of histone H3 K36. Nat Cell Biol 2005;7(12):1256-60.

[120] Kim SY, He Y, Jacob Y, Noh YS, Michaels S, Amasino R. Establishment of the vernalization-responsive, winter-annual habit in Arabidopsis requires a putative histone H3 methyl transferase. Plant Cell 2005;17(12):3301-10.

[121] Penheiter KL, Washburn TM, Porter SE, Hoffman MG, Jaehning JA. A posttranscriptional role for the yeast Paf1-RNA polymerase II complex is revealed by identification of primary targets. Mol Cell 2005;20(2):213-23.

[122] Simpson GG, Dijkwel PP, Quesada V, Henderson I, Dean C. FY is an RNA 3 end-processing factor that interacts with FCA to control the Arabidopsis flora transition. Cell 2003;113(6):777-87.

[123] Quesada V, Macknight R, Dean C, Simpson GG. Autoregulation of FCA premRNA processing controls Arabidopsis flowering time. EMBO J 2003;22(12): 3142-52.

[124] Swiezewski S, Crevillen P, Liu F, Ecker JR, Jerzmanowski A, Dean C. Small RNA-mediated chromatin silencing directed to the 3' region of the Arabidopsis gene encoding the developmental regulator, FLC. Proc Natl Acad Sci USA 2007;104(9):3633-8. 
[125] Baurle I, Smith L, Baulcombe DC, Dean C. Widespread role for the floweringtime regulators FCA and FPA in RNA-mediated chromatin silencing. Science 2007;318(5847):109-12.

[126] Cloos PA, Christensen J, Agger K, Helin K. Erasing the methyl mark: histone demethylases at the center of cellular differentiation and disease. Genes Dev 2008;22(9):1115-40.

[127] Forneris F, Binda C, Battaglioli E, Mattevi A. LSD1: oxidative chemistry for multifaceted functions in chromatin regulation. Trends Biochem Sci 2008;33(4):181-9.

[128] Lan F, Nottke AC, Shi Y. Mechanisms involved in the regulation of histone lysine demethylases. Curr Opin Cell Biol 2008;20:316-25.

[129] Metzger E, Wissmann M, Yin N, Muller JM, Schneider R, Peters AH, et al. LSD1 demethylates repressive histone marks to promote androgen-receptordependent transcription. Nature 2005;437(7057):436-9.

[130] Shi Y, Lan F, Matson C, Mulligan P, Whetstine JR, Cole PA, et al. Histone demethylation mediated by the nuclear amine oxidase homolog LSD1. Cell 2004;119(7):941-53.

[131] He Y, Michaels SD, Amasino RM. Regulation of flowering time by histone acetylation in Arabidopsis. Science 2003;302(5651):1751-4.

[132] Jiang D, Yang W, He Y, Amasino RM. Arabidopsis relatives of the human lysinespecific Demethylase 1 repress the expression of FWA and FLOWERING LOCUS $C$ and thus promote the floral transition. Plant Cell 2007;19(10):2975-87.

[133] Sanda SL, Amasino RM. Ecotype-specific expression of a flowering mutant phenotype in Arabidopsis thaliana. Plant Physiol 1996;111(2):641-4.

[134] Lee MG, Wynder C, Bochar DA, Hakimi MA, Cooch N, Shiekhattar R. Functional interplay between histone demethylase and deacetylase enzymes. Mol Cell Biol 2006;26(17):6395-402.

[135] Shi YJ, Matson C, Lan F, Iwase S, Baba T, Shi Y. Regulation of LSD1 histone demethylase activity by its associated factors. Mol Cell 2005;19(6):857-64.

[136] Krichevsky A, Gutgarts H, Kozlovsky SV, Tzfira T, Sutton A, Sternglanz R, et al. $\mathrm{C} 2 \mathrm{H} 2$ zinc finger-SET histone methyltransferase is a plant-specific chromatin modifier. Dev Biol 2007;303(1):259-69.
[137] Kinoshita Y, Saze H, Kinoshita T, Miura A, Soppe WJ, Koornneef M, et al. Control of FWA gene silencing in Arabidopsis thaliana by SINE-related direct repeats. Plant J 2007;49(1):38-45.

[138] Saze H, Mittelsten Scheid O, Paszkowski J. Maintenance of CpG methylation is essential for epigenetic inheritance during plant gametogenesis. Nat Genet 2003;34(1):65-9.

[139] Soppe WJ, Jacobsen SE, Alonso-Blanco C, Jackson JP, Kakutani T, Koornneef $\mathrm{M}$, et al. The late flowering phenotype of fwa mutants is caused by gain-of-function epigenetic alleles of a homeodomain gene. Mol Cell 2000;6(4):791-802.

[140] Balciunas D, Ronne H. Evidence of domain swapping within the jumonji family of transcription factors. Trends Biochem Sci 2000;25(6):274-6.

[141] Takeuchi T, Watanabe Y, Takano-Shimizu T, Kondo S. Roles of jumonji and jumonji family genes in chromatin regulation and development. Dev Dyn 2006;235(9):2449-59.

[142] Tian X, Fang J. Current perspectives on histone demethylases. Acta Biochim Biophys Sin (Shanghai) 2007;39(2):81-8.

[143] Noh B, Lee SH, Kim HJ, Yi G, Shin EA, Lee M, et al. Divergent roles of a pair of homologous jumonji/zinc-finger-class transcription factor proteins in the regulation of Arabidopsis flowering time. Plant Cell 2004;16(10):2601-13.

[144] Saze H, Shiraishi A, Miura A, Kakutani T. Control of genic DNA methylation by a jmjC domain-containing protein in Arabidopsis thaliana. Science 2008;319(5862):462-5.

[145] Yu X, Li L, Li L, Guo M, Chory J, Yin Y. Modulation of brassinosteroid-regulated gene expression by jumonji domain-containing proteins ELF6 and REF6 in Arabidopsis. Proc Natl Acad Sci USA 2008;105:7618-23.

[146] Domagalska MA, Schomburg FM, Amasino RM, Vierstra RD, Nagy F, Davis SJ. Attenuation of brassinosteroid signaling enhances FLC expression and delays flowering. Development 2007;134(15):2841-50.

[147] Kim SY, Michaels SD. SUPPRESSOR OF FRI 4 encodes a nuclear-localized protein that is required for delayed flowering in winter-annual Arabidopsis. Development 2006;133:4699-707. 